\title{
Incorporation in Offshore Financial Centers: \\ Naughty or Nice?
}

\section{Warren Bailey and Edith X. Liu *}

\author{
Cornell University \\ 31st December 2012 \\ Very preliminary: please do not quote or distribute
}

\begin{abstract}
We study associations between measures of firm value and quality and the firm's choice of legal and regulatory environment though incorporation in an offshore financial center. Preliminary empirical results suggest that incorporation in such a jurisdiction, or switching incorporation to one, is associated with lower value as measured by Tobin's $q$. This effect varies with the quality of the firm's home country environment and the offshore domicile it selects.
\end{abstract}

Keywords: Offshore financial center, tax haven, law and finance, corporate governance

EFM classifications: 150,630

* Johnson Graduate School of Management, 387 Sage Hall, Ithaca NY 14850 U.S.A., (607) 255-4627, wbb1@cornell.edu; Dyson School of Applied Economics and Management, 466 Warren Hall, Ithaca, NY 14853 U.S.A., (607) 354-8308, edith.liu@,cornell.edu. We thank Andrew Karolyi, Ying Wu, and seminar participants at Shanghai Advanced Institute of Finance and University of International Business and Economics for helpful discussions. 


\section{Introduction}

There is much evidence that the legal, regulatory, and disclosure environment is related to firm value and quality. For example, Daines (2001) finds that US firms incorporated in Delaware have higher value and are more likely to experience takeover attempts than other firms. ${ }^{1}$ Doidge, Karolyi, and Stulz (2004) find that cross listing of a non US firm in the US is associated with a substantially higher Tobin's $q$ relative to non US firms that do not list in the $\mathrm{US}^{2}$

This evidence is interesting and important because it contributes to our understanding of how firms select legal and regulatory environment to benefit ordinary shareholders versus management or insiders. The objectives and workings of the environment a firm selects can have substantial consequences. ${ }^{3}$ A firm can choose an environment that enhances its value or signals its intention to improve. Alternatively, a firm can avoid environments that are expensive, intrusive, and impede the ability for managers to expropriate from ordinary shareholders (Fernandes, Lel, and Miller, 2010; Doidge, Karolyi, and Stulz, 2010). Some jurisdictions attract incorporations with a high quality value-enhancing legal regime while others offer weak law, regulation, and disclosure that allow management to benefit at the expense of other owners. Furthermore, whether or not off-shore incorporation enhances firm

\footnotetext{
${ }^{1}$ Bebchuk and Cohen (2003) and Subramanian (2004) find this is sensitive to the time period.

2 The choice of venue to incorporate can affect other corporate decisions and, thus, value. See, for example, the findings of Wald and Long (2007) that leverage decisions of US firms depend on which US state a manufacturer chooses to incorporate in.

${ }^{3}$ See, for example, poison pill studies like Malatesta and Walking (1988) and Comment and Schwert (1995).
} 
value depends on the legal environment and characteristics of both the offshore legal host country and the home country.

While the cross-listing literature assesses the benefits of listing in a stronger legal and regulatory environment, this paper seeks supporting evidence in the opposite direction, choosing a less demanding environment that benefits managers and insiders at the expense of ordinary shareholders. In particular, we evaluate firms that select an alternative legal and regulatory system by incorporating in an offshore financial center (OFC). Jurisdictions ranging from city-states to tiny island dependencies structure their legal and regulatory regimes to encourage many financial activities including incorporation of foreign firms (Lane and Milesi-Ferretti, 2010). Places like Bermuda, the British Virgin Islands, and the Cayman Islands compete with larger capital markets and can offer low-cost, efficient legal conditions that can enhance firm value and pressure other jurisdictions to improve (Morriss, 2010). At the same time, OFCs have been accused of enabling mis-management and expropriation by self-serving corporate managers or controlling owners, in addition to tax evasion, accounting opacity and other questionable or illegal behavior (Mendis, Suss, Williams, and Mendis, 2002; Zoromé, 2007). ${ }^{4}$

\footnotetext{
${ }^{4}$ See "At Orient Express, the Board holds All the Cards", New York Times Dealbook, $29^{\text {th }}$ November 2012 , (http://dealbook.nytimes.com/2012/11/29/at-orient-express-the-board-holds-all-the-cards/) for an example of how managers can control a firm and their own employment conditions under Bermuda law.
} 
We study the value and other characteristics of firms incorporated in OFCs relative to other firms, the effect of a firm moving its incorporation to or from an OFC, and the performance of initial public offerings of firms incorporated in foreign OFCs. We seek to understand whether incorporation in an OFC improves or detracts from corporate value and quality. In doing so, we shed light on the motivations of these firms and the jurisdictions that compete to attract them. We focus on OFCs because they offer corporations an extreme form of jurisdiction-shopping that has become increasingly controversial.

\section{Offshore Financial Centers}

What exactly is an offshore financial center? We can think of such a place as an economy specializing in providing financial services to non-residents? Zoromé (2007) cites several more specific definitions from IMF publications of the last decade or two. For example:

“...'the banking system, acting as financial entrepôt, acquires substantial external accounts beyond those associated with economic activity in the country concerned,' or countries where the ratio of deposit banks' external assets to exports of goods and services is significantly higher than the world average.” 
“...a jurisdiction in which its international investment position assets, including as resident all entities that have legal domicile in that jurisdiction, are close to or more than 50 percent of GDP and in absolute terms more than \$1 billion."

The scale of activity in OFCs is difficult to measure as statistics are often sparse, but the amount of financial activity in these places seems large. In Bermuda in 2003, for example (Zoromé, 2007; Table 8), net export of financial services was $42 \%$ of GDP and portfolio assets were over 100 times GDP. Jurisdictions with the 2003 ratio of net export of financial services to GDP more than two standard deviations above the mean include Bahrain, Barbados, Bermuda, Cayman Islands, Guernsey, Hong Kong, Isle of Man, Jersey, Latvia, Luxembourg, Mauritius, Netherlands Antilles, Panama, Singapore, Switzerland, Uruguay, and Vanuatu. Offshore banks hold about one-eighth of global bank assets. OFC activities can contribute significantly to government revenue and employment in a small economy, ${ }^{5}$ diversifying away from traditional sectors such as agriculture and tourism.

Because much of the activity in OFCs relates to corporation and personal taxation, these jurisdictions are often referred to as "tax havens". Hines and Rice (1994) study the use of tax haven affiliates by US corporations. They find that these affiliates account for about $20 \%$ of

\footnotetext{
5 In 2001 for the British Virgin Islands, for example, Suss, Williams, and Mendis (2002) report there were over 300,000 "international business corporations", and 15\% of all local employment and 55\% of government revenue related to $\mathrm{OFC}$ functions.
} 
all US foreign direct investment, and suggest that they are motivated by low tax rates. Desai, Foley, and Hines (2006) detail the characteristics of US multinationals that use OFCs and the nature of the tax advantages they gain. Dyreng and Lindsey (2009) measure a significant tax saving for US firms who use at least one OFC. These papers demonstrate how OFCs can generate value for foreign corporations by reducing taxes.

Morriss (2010) notes that OFCs help US corporations lower the cost of insurance and employee healthcare, ${ }^{6}$ allow many multinationals to make full use of international tax treaties, and benefit Chinese investors with a more secure and predictable legal system. At the same time, he mentions prominent events in which OFCs are associated with local government corruption, the narcotics trade, financial fraud, and tax evasion. OFCs certainly offer substantially different conditions to foreign companies compared to their home environments. For example, incorporation in the British Virgin Islands features no disclosure requirements, minimal numbers of directors and shareholders, management anonymity, and ease of transfer of corporate assets, in addition to tax exemptions. ${ }^{7}$ Whether OFCs facilitate healthy

\footnotetext{
${ }^{6}$ An extreme example is hedge funds setting up offshore reinsurance units that invest back into the hedge fund. See "With Lax Regulation, a Risky Industry Flourishes Offshore, in New York Times Dealbook, $5^{\text {th }}$ September 2012, (http://dealbook.nytimes.com/2012/09/04/with-lax-regulation-a-risky-industry-flourishes-offshore/).

${ }^{7}$ See http://www.bviifc.gov.vg/FinancialSectors/CorporateBusiness/Advantages/tabid/157/Default.aspx. For a discussion of the potential tax, governance, and regulatory advantages of Michael Kors Holdings incorporating in the British Virgin Islands while being headquartered in Hong Kong see "The Benefits of Incorporating Abroad in an Age of Globalization”, New York Times Dealbook, $20^{\text {th }}$ December 2011, (http://dealbook.nytimes.com/2011/12/20/the-benefits-of-incorporating-abroad-in-an-age-of-globalization/) .
} 
competition between jurisdictions or a "race to the bottom" continues to be debated. ${ }^{8}$ In the model of Bar-Gill, Barzuza, and Bebchuk (2006), reincorporation improves the welfare of shareholders on some dimensions (such as Delaware's court system or an OFC's tax system) at the cost of freeing insiders to expropriate more wealth. Competition from other jurisdictions limits the revenue that an OFC can extract from firms. ${ }^{9}$ Thus, the costs and benefits associated with a firm's choice of jurisdiction for incorporation are complex. Our evidence clarifies the net effect of OFC incorporation by relating it to firm value.

An anecdote illustrates the ambiguous potential impact of re-incorporation in an OFC. Tyco International, a US listed corporation, moved its legal domicile from Bermuda to Switzerland in 2009. The company's 2009 10-K annual report states that the change in incorporation will enhance "our ability as a Swiss company to take advantage of the tax treaties between Switzerland and the United States". On the same page, "there continues to be

\footnotetext{
8 For example, Hong Kong's Jardine group of companies reorganized under a Bermuda-domiciled holding company in 1984. Aspects of Bermuda law were thought to enhance the Keswick family's control of the group, which could protect the company once control of Hong Kong returned to China in 1997 or could increase the power of insiders relative to minority shareholders.

9 For example, the maximum annual corporate franchise fee is about $\$ 30,000$ in Bermuda and only a few thousand dollars per year in the British Virgin Islands or the Cayman Islands (www.taxrates.cc). For comparison, Delaware's maximum annual fee is $\$ 180,000$ (corp.delaware.gov/frtaxcalc.shtml). Public information on the specific legal expenses of incorporation or re-incorporation of a substantial listed public company does not seem available See, for example, http://www.calstrs.com/Newsroom/whats_new/cominghomeISS.aspx concerning Tyco International. Tyco's Form S-4 dated $10^{\text {th }}$ December 2008 states (page 23) “...we do not expect these costs to be material..." Consent of the shareholders and directors must be obtained. According to law firm websites, a straightforward incorporation of a small firm would cost several thousand dollars in legal fees. See "The incorporation business: They sell sea shells", The Economist, $7^{\text {th }}$ April 2012, http://www.economist.com/node/21552197/print.
} 
negative publicity regarding, and criticism of, companies that conduct substantial business in the U.S. but are domiciled abroad". The document goes on to say "Because of differences between Swiss law and Bermuda law and differences between the governing documents of Swiss and Bermuda companies, it may not be possible to enforce court judgments obtained in the United States...in Switzerland”. Thus, incorporation in an OFC can convey benefits such as tax advantages or can harm shareholders by reducing their ability to control management or damaging the company's reputation.

The OECD's Financial Action Task Force in 2000 and 2001 declared a number of OFCs to be "non-cooperative" for issues such as money laundering, weak law or regulation, obstructing international law enforcement, and inadequate allocation of resources to law and regulation.

International organizations have continued to monitor, offer assistance, and apply pressure to OFCs to upgrade the quality of their legal, regulatory, and disclosure environments (International Monetary Fund, 2006, 2008). However, there is continued concern about the uses and abuses of OFCs given involvement in recent scandals (van der Does de Willebois, Halter, Harrison, Park, and Sharman, 2011; Shaxson, 2011) and continued easy creation of shell companies and other offshore entities. While there is almost no academic research on OFCs, what little exists suggests that OFCs are associated with poorer-quality firms (Durnev, Li, and Magnan, 2011). Evidence on announcement effects and other dimensions of valuation 
surrounding the incorporation event in OFCs is mixed. ${ }^{10}$ Adding to the controversy, some OFCs were heavily involved in the US securitization boom which fed the recent financial crisis (Lane and Milesi-Ferretti, 2010).

A recent development is the increase in problems associated with OFC-incorporated Chinese companies listed in US and other non-Chinese stock markets. The growth in China's economy has outpaced legal, regulatory, and disclosure practices. Several Chinese corporations that listed in the US have suffered from management problems and scandals (see, for example, Hung, Wong, and Zhang, 2011). Regulators explicitly mention the entry of problematic Chinese companies to US stock markets using reverse mergers (Public Company Accounting Oversight Board, 2011; United States Securities and Exchange Commission, 2011). Furthermore, some of the OFC-related structures employed by Chinese firms to list a holding company in the U.S. appear to violate Chinese law. ${ }^{11}$ The variety of problems surrounding Chinese companies has attracted both law enforcement and aggressive stock traders from beyond mainland China. ${ }^{12} \mathrm{Ang}$, Jiang, and $\mathrm{Wu}$ (2012) explore the

${ }^{10}$ Desai and Hines (2002) find an average announcement response of $1.7 \%$ for 19 US firms moving incorporation to an OFC from 1993 to 2002. Durnev, Li, and Magnan (2012) find that small positive announcement effects for registering or establishing a subsidiary in an OFC vanish after 2002 while valuation is lower except for UK and US firms establishing OFC subsidiaries.

11 See “China’s Forbidden Investment, 1 st March 2012, http://www.rkmc.com/publications/articles/china-s-forbidden-investment.

12 See

http://dealbook.nytimes.com/2012/01/27/f-b-i-searches-offices-of-n-y-adviser-on-chinese-reverse-mergers http://www.reuters.com/article/2011/06/06/businesspro-us-china-stocks-muddywaters-idUSTRE7556D0201106 $\underline{06}$. 
characteristics of US listed Chinese firms that have been involved in scandals. They find that listing by reverse merger, greater earnings management, and weaker corporate governance predict greater likelihood of scandal. Many of the recent US listings from China are incorporated in offshore financial centers, particularly the Cayman Islands. ${ }^{13}$ From a broader perspective, this paper studies the contribution of OFC incorporation to the frequency and cost of these scandals.

\section{Empirical design}

\subsection{Testable hypotheses}

Doidge, Karolyi, and Stulz (2004) present a simple model to explain whether a non US firm chooses to list on a US stock market. In deciding whether to list shares in the US, a non US firm's controlling shareholders face a trade-off. The firm can grow faster raising capital and dealing with stakeholders under the extensive investor protection of the US legal and regulatory system, but this constrains the ability of controlling shareholders to expropriate minority shareholders. If cross-listing in the US imposes higher legal and regulatory standards on a non US firm, the firm increasing its value by cross-listing in the US.

\footnotetext{
13 See Darrough, Huang, and Zhao (2012), Jindra, Voetmann, and Walkling (2012), and Givoly, Hayn, and Lourie (2012) for further evidence on Chinese firms listed in the US and, in particular, on the associations between reverse listing and firm quality.
} 
Similarly, we can imagine that incorporation in an offshore financial center can move a firm in the other direction, that is, to a less-demanding environment, but at the same time offer potential expropriation benefits to insiders and tax benefits to all shareholders. Therefore, we adapt the setting, notation, and solution of Doidge, Karolyi, and Stulz (2004) to the case where investor protection afforded by incorporation at home, $\rho_{\text {home, }}$ is greater than the investor protection when incorporated in an offshore financial center, $\rho_{\text {ofc }}$. Controlling shareholders are entitled to a fraction, $k$, of the cash flow, $C$, of the firm and select the fraction, $f$, of firm cash flow that they expropriate beyond $\mathrm{kC} .{ }^{14}$ Expropriation imposes a cost which is quadratic in the fraction expropriated and linearly increasing in the quality of investor protection, $\rho$, in the jurisdiction where the firm chooses to incorporate. Furthermore, if the firm is incorporated not at home but in an OFC, it loses the opportunity to finance growth opportunities worth z but gains tax benefits worth $\tau$.

Thus, controlling shareholders enjoy the following gain if incorporated at home:

$$
\mathrm{k}\left[(\mathrm{C}+\mathrm{z})-\mathrm{f}(\mathrm{C}+\mathrm{z})-1 / 2 \mathrm{~b} \mathrm{f}^{2} \rho_{\text {home }}(\mathrm{C}+\mathrm{z})\right]+\mathrm{f}(\mathrm{C}+\mathrm{z})
$$

where $\mathrm{b}$ is a constant greater than zero. In (1), the term in brackets is the cash flow of the firm minus expropriation and minus its deadweight cost. The term, $\mathrm{f}(\mathrm{C}+\mathrm{z})$, on the right is the benefit

\footnotetext{
${ }^{14} \mathrm{C}$ is assumed to be exogenous but we can imagine a more complex model in which managerial decisions such affect the distribution and value of $\mathrm{C}$ and are enabled or discouraged by the legal and regulatory system the firm chooses.
} 
from expropriation enjoyed by controlling shareholders. The gain to controlling shareholders if incorporated in an offshore financial center is:

$$
\mathrm{k}\left[(\mathrm{C}+\tau)-\mathrm{f}(\mathrm{C}+\tau)-1 / 2 \mathrm{bf}^{2} \rho_{\text {ofc }}(\mathrm{C}+\tau)\right]+\mathrm{f}(\mathrm{C}+\tau)
$$

Solve the maximization problem over $\mathrm{f}$ in both home and $\mathrm{OFC}$ incorporated situations and substitute the solution into the original expressions to yield the total gain of the controlling shareholders if incorporated at home:

$$
\mathrm{k}(\mathrm{C}+\mathrm{z})+1 / 2\left[(1-\mathrm{k})^{2} / \mathrm{b} \rho_{\text {home }} \mathrm{k}\right](\mathrm{C}+\mathrm{z})
$$

and their total gain if incorporated in an OFC:

$$
\mathrm{k}(\mathrm{C}+\tau)+1 / 2\left[(1-\mathrm{k})^{2} / \mathrm{b} \rho_{\text {ofc }} \mathrm{k}\right](\mathrm{C}+\tau)
$$

Controlling shareholders will choose to incorporate in an OFC if their gain, (4) exceeds that for incorporation at home, (3). Let $\Theta$ equal the parameter $1 / 2(1-\mathrm{k})^{2} / \mathrm{bk}$ :

$$
\mathrm{k}(\mathrm{C}+\mathrm{z})+\left(\Theta / \rho_{\text {home }}\right)(\mathrm{C}+\mathrm{z})<\mathrm{k}(\mathrm{C}+\tau)+\left(\Theta / \rho_{\text {ofc }}\right)(\mathrm{C}+\tau)
$$

The left-hand side is the payoff from incorporating at home and financing greater growth. The right-hand side is the payoff from greater expropriation by incorporation in an OFC. Rearranging yields:

$$
\mathrm{k}(\tau-\mathrm{z})+\Theta\left[\left((\mathrm{C}+\tau) / \rho_{\text {ofc }}\right)-\left((\mathrm{C}+\mathrm{z}) / \rho_{\text {home }}\right)\right]>0
$$

The comparative statics in Doidge, Karolyi, and Stulz (2004) imply, first, that growth opportunities dissuade firms from incorporating in an $\mathrm{OFC}$, and, second, that expropriation opportunities encourage firms to incorporate in an OFC. This is confirmed formally in $(5 b)$. 
Controlling insiders will select incorporation in an OFC if growth opportunities, $\mathrm{z}$, are low relative to tax savings, $\tau$, and expropriation is much easier in an OFC (that is, $1 / \rho_{\text {home }}$ versus $\left.1 / \rho_{\text {ofc }}\right)$.

We can also see how value differs from the point-of-view of minority outside shareholders who do not enjoy any of the expropriation benefits of control. The firm's cash flow if incorporated at home and controlling shareholders have optimized $\mathrm{f}$ is:

$$
(\mathrm{C}+\mathrm{z})\left(1-\left[\left(\Theta / \rho_{\text {home }}\right)(1+\mathrm{k}) /(\mathrm{k}(1-\mathrm{k})]\right.\right.
$$

The firm's cash flow if incorporated in an OFC and controlling shareholders have optimized fi $(\mathrm{C}+\tau)\left[1-\left(\Theta / \rho_{\text {ofc }}\right)(1+\mathrm{k}) /(\mathrm{k}(1-\mathrm{k}))\right]$

The results in Doidge, Karolyi, and Stulz (2004) imply that firms incorporated in an OFC sell at a discount relative to firms incorporated at home, and that discount is increasing in growth opportunities and the distance between $\rho_{\text {home }}$ and $\rho_{\text {ofc }}$. In our case, the premium for incorporating at home, (6a) minus (6b), is slightly more complicated because there is a potential benefit, tax savings, to OFC incorporation in our model. Subtracting (6b) from (6a) and simplifying yields:

$$
(\mathrm{z}-\tau)-(\mathrm{C}+\mathrm{z})\left[\left(\Theta / \rho_{\text {home }}\right)(1+\mathrm{k}) /(\mathrm{k}(1-\mathrm{k})]+(\mathrm{C}+\tau)\left[\left(\Theta / \rho_{\text {ofc }}\right)(1+\mathrm{k}) /(\mathrm{k}(1-\mathrm{k}))\right]\right.
$$

In (7), the first term illustrates the trade-off between the value of growth enabled by incorporation at home versus the value of tax shields enjoyed if incorporated in an OFC. The 
second term enters (7) with a negative sign, indicating that the premium for incorporation at home increases with investor protection: with larger $\rho_{\text {home }}$ the term vanishes. The third term enters (7) with a positive sign, indicating that the premium for incorporation at home increases with lower investor protection in the OFC: with lower $\rho_{\text {ofc }}$ the term grows and the home premium becomes more positive. Finally, recall the composition of the parameter $\Theta$, which equals $1 / 2(1-\mathrm{k})^{2} / \mathrm{bk}$ and is therefore always positive. The fraction, $\mathrm{k}$, of cash flow rights held by insiders is exogenous in this model. When k equals one, $\Theta$ is zero and (3) and (4) show that there is no gain to expropriation because insiders are stealing dollar-for-dollar from themselves, and at a cost.

In thinking about how incorporation in an OFC can affect value, note that we need not constrain $\rho_{\text {home }}$ to be greater than $\rho_{\text {ofc }}$. If an OFC offers a simple, low-cost, effective legal environment for firms that incorporate there, we have $\rho_{\text {ofc }}$ greater than $\rho_{\text {home, }}$ less rather than more expropriation occurs when a firm incorporates in the OFC, and firm value and other qualities are enhanced rather than weakened. Furthermore, Doidge, Karolyi, and Stulz (2007) extend the model of Doidge, Karolyi, and Stulz (2004) to include firm level governance in addition to country level governance. Among their comparative statics, firm governance, $\mathrm{q}$, is less likely to be changed if its cost of implementation, $\mathrm{m}$, is high, and firm level governance increases if its complement, country level governance, decreases. 
With the theoretical findings of Doidge, Karolyi, and Stulz $(2004,2007)$ in mind, we offer the following testable hypotheses. Some of the predictions compare OFC-incorporated firms to control firms that share their home country. Other predictions imply consequences from a change in incorporation to or from an OFC. We begin with a simple null:

H0: Incorporation in an OFC is irrelevant and, after controlling for firm characteristics, there is no valuation difference between firms from non OFC countries that incorporate in an OFC versus firms from a non OFC country that incorporate in their own country.

Next we compare OFC incorporated firms to non OFC incorporated firms under the assumption that OFCs offer a weaker legal and regulatory environment:

H1: Incorporation in an OFC allows controlling shareholders of a non OFC firm to avoid legal and regulatory discipline and expropriate more benefits from minority shareholders.

Specific implications of $\mathrm{H} 1$ and our adaptation of the models of Doidge, Karolyi, and Stulz (2004, 2007) compare firms incorporated in an OFC to other firms: 
H1a: Firms incorporated in an OFC have lower value, poorer governance and corporate disclosure quality, and lower growth opportunities than other firms.

H1 also leads to a prediction about what happens when a firm moves its incorporation:

H1b: Firm value and quality of governance and disclosure decline when a firm incorporates in an OFC and increase when it moves incorporation away from an OFC

H1b suggests an event study or before-versus-after test for firms that have changed their incorporation to or from an OFC. We can also offer cross-sectional predictions based on firm and home country characteristics:

H1c: The effects predicted by H1a and H1b are heightened for firms located in high quality environments that choose to incorporate in an $\mathrm{OFC}$, for firms that incorporate in an OFC with a particularly weak legal and regulatory regime, for firms with low growth opportunities or no need for external capital, and for firms that suffer no penalty for expropriating minority shareholders. 
H1 and its related hypotheses are based on the idea that the OFC offers an undemanding environment that weakens firm value and quality because $\rho_{\text {ofc }}$ is less than $\rho_{\text {home. }}$ In contrast to the spirit of $\mathrm{H} 1$ and related hypotheses, we can imagine cases when $\rho_{\text {ofc }}$ exceeds $\rho_{\text {home }}$ and incorporation in an OFC enhances value:

$\mathrm{H} 2$ : For firms originating in an environment of lower legal and regulatory quality than an $\mathrm{OFC}$, incorporation in an $\mathrm{OFC}$ increases firm value.

For example, this could apply to firms from China, which has a very underdeveloped legal and regulatory environment. Given the high growth opportunities offered by the Chinese economy, incorporation in an OFC could make it easier for firms without sufficient retained earnings to raise funds externally. ${ }^{15}$ Alternatively, moving incorporation from a demanding and intrusive home environment to a lower-quality OFC can lower the cost of compliance, thereby enhancing the raw cash flow, C, available to shareholders. ${ }^{16} \mathrm{H} 2$ also implies additional hypotheses $\mathrm{H} 2 \mathrm{a}, \mathrm{H} 2 \mathrm{~b}$, and $\mathrm{H} 2 \mathrm{c}$ that make more specific predictions to help us interpret our empirical findings.

15 See Allen, Qian, and Qian (2005) and Bailey, Huang, and Yang (2011) concerning the reliance of Chinese firms on retained earnings for investment.

${ }^{16}$ See, for example, Doidge, Karolyi, and Stulz (2010) on foreign firms terminating their SEC registration when faced with the cost of complying with the Sarbanes-Oxley Act. 
The model of Doidge, Karolyi, and Stulz (2007) shows how country level and firm level governance can complement each other. Therefore:

H3: Firms from higher quality home country environments that incorporate in an OFC increase the quality of their firm specific governance to compensate for the lower quality environment in an OFC.

A firm can incorporate in an OFC for reasons, such as taxes, fear of disclosure of competitive secrets, or protection against state expropriation in their home country, that have nothing to do with expropriating its own minority shareholders.

Finally, we also view the value-creation $(\mathrm{H} 1)$, value destruction $(\mathrm{H} 2)$, or irrelevance $(\mathrm{H} 0)$ of incorporation in an OFC through the lens of initial public offering under-pricing. A signaling approach to IPO under-pricing starts with the idea that managers and controlling shareholders have private information about a firm's quality. In some models, a high quality firm signals its prospects to uninformed investors by offering shares at a discount, the cost of which is expected to be recovered when the firm's prospects are revealed and subsequent seasoned equity offerings sell at higher valuations. ${ }^{17}$ Under H1 (H2), IPO under-pricing is less (more)

17 See, for example, Allen and Faulhaber (1989), Welch (1989), and Grinblatt and Hwang (1989). 
severe for OFC-incorporated firms after controlling for other firm characteristics. Alternatively, the IPO literature features other models that offer interesting competing predictions. ${ }^{18}$

\subsection{Data}

\subsubsection{Firms and firm characteristics}

We identify firms to include in the study as follows. First, we aggregate firms from Datastream, Worldscope, ADR, and CompustatNA. The resulting database include the current constituent list of all active, dead, and suspended firms from Datastream; all active ADRs from adr.com and adrbnymellon.com; all firms on CompactD Worldscope CD-ROMs from Jan 1992 to July 2006; and all firms on Compustat North America from January 1980 to January 2012. Country of incorporation is the country code (the first two digits) of the ISIN identifier, except for Compustat NA where we use the "fic" variable. For ADRs, we use the ISIN code of the underlying firm. To identify the address country, the variables "Nation" in Datastream, "loc" in Compustat North America, and "Country" in ADRs and Worldscope CompactD are used.

Given each firm is now associated with a country of incorporation and a country of address, we retain for the OFC sample only those firms with country of incorporation among the OFCs listed in International Monetary Fund (2006). This yields a total of 7,990 firms. We then eliminate firms that have the same country of address and country of incorporation. This

18 See, for example, Tinic (1988) and Hughes and Thakor (1992) for models in which low quality firms under-price IPOs to reduce the chance of lawsuits by disappointed shareholders who buy shares. 
excludes local OFC companies, leaving 2,819 distinct firms. ${ }^{19}$ Next, we obtain annual firm-level financial variables Total Assets, Sales, Long Term Debt, Total Debt, Shareholder's Equity, and Market Value of Equity from Datastream and Compustat North America for January 1980 to December $2011 .^{20}$ Firms with any missing financial series are automatically eliminated. Because firms can have missing observations for some variables and years, Firm-year observations with missing Total Assets, Shareholder's Equity, and Market Value are excluded as they are the necessary compute Tobin's $q$. Firm-year observations with less than four years of consecutive sales are dropped, as computing three year sales growth requires four years of consecutive sales data. This yields a total of 1,372 firms for the OFC incorporated sample.

We also construct a control sample. We begin with all firms in Datastream with the same countries of address as the firms in the OFC sample, then eliminate firms for which country of incorporation differs from address country. Next, each of the resulting set of firms is matched with its financial variables. Paralleling the construction of the OFC sample described above, we eliminate any firm with missing financial variables and any firm-year observation that is missing Total Assets, Shareholder's Equity, and Market Value or does not have at least 4

\footnotetext{
19 A distinct firm can have more than one stock exchange listing. Also note that our filter does not exclude cross-OFC firms such as a Bermuda address firm incorporated in the Cayman Islands.

${ }^{20}$ Firms are matched by isinno in Datastream and gvkey in CompustatNA. Each firm-year observation includes , the foreign exchange spot rate for the currency as of the fiscal year end date so financial variables can be expressed in US dollars.
} 
years of Sales data. This yields a control sample of 15,816 firms.

We gather or construct firm-specific characteristics as follows. For each OFC and control firm, we construct annual balance sheet and income statement variables such as Total Assets in US dollars and three-year Sales Growth. Tobin's $q$ is computed for each firm-year as (Market Value of Equity + Total Assets - Shareholder's Equity) divided by Total Assets. From I/B/E/S, we gather three measures of the information environment by firm-year, the number of analysts providing forecasts, the standard deviation of those forecasts, and the absolute value of the percent earnings surprise. They measure the amount of analyst resources devoted to the firm and the extent of disagreement and uncertainty about the firm's value. Finally, we create a cross-listing dummy variable to identify any firm-year in which the firm has cross-listed from the US. As previously documented by Doidge et al (2004), a non US firm that cross-lists in the US commits to a higher level of corporate governance and typically receives a premium as a consequence.

\subsubsection{Country characteristics}

We collect standard proxies for the legal and investment environment in the address countries of our OFC-incorporated and control firms. They can be thought of as specific dimensions of the environment faced by corporations in a particular country or as general indicators of the overall quality of that environment. Borrowing from Doidge, Karolyi, and 
Stulz (2004, 2007) and Bailey, Karolyi, and Salva (2006), we begin with the legal origin, index of anti-director rights, index of judicial efficiency, and index of accounting standards from La Porta, Lopez-de-Silanes, Shleifer, and Vishny (1998). We compress the country legal origin indicated by La Porta et al (1998) into a single dummy variable equal to one for English law jurisdictions and zero otherwise. Their paper does not classify legal origin for all jurisdictions, particularly smaller one, so we refer to www.indexmundi.com to complete the series.

The country characteristics described to this point suffer from two shortcomings given the nature of the home countries and OFC countries that our sample of firms is associated with. First, many of our most interesting and controversial firms come from the People's Republic of China, but the La Porta et al (1998) indexes do not include this country given its complex and continuing evolution away from a centrally-planned command economy. Second, we are interested in the characteristics of both countries where firms do business and countries or jurisdictions where firms are incorporated. The smaller OFC countries are also not included in the La Porta et al (1998) indexes.

Given these problems, we collect additional series to augment or substitute for the La Porta et al (1998) series as follows. First, Djankov, LaPorta, Lopez-de-Silanes, and Shleifer (2003) measure the time, in days, to complete two basic legal procedures (collecting on a bounced check, evicting a tenant for nonpayment of rent) across dozens of countries including 
China and many of our OFCs. They reflect the quality and efficiency of the workings of a country's legal system. Second, The Milken Institute Capital Studies Group computes a Capital Access Index that measures the ability of an entrepreneur to raise capital in a particular country). It is a proxy for the state of development and efficiency of capital markets in a country and comprises indexes of Macroeconomic environment, Institutional environment, Financial and banking institutions, Equity market development, Bond market development, Alternative sources of capital, and International funding. ${ }^{21}$ The index is available yearly starting with 1998. Fourth, the World Bank's Worldwide Governance Indicators (WGI) measure six dimensions (Voice \& Accountability, Political Stability and Lack of Violence, Government Effectiveness, Regulatory Quality, Rule of Law, and Control of Corruption) for over 200 countries, and are available annually from $1996 .{ }^{22}$ Finally, the World Bank's “Doing Business" indicators (DB) for disclosure, legal rights, credit information, director liability, and shareholder suits (www.doingbusiness.org) offer another measure of the quality of the business environment in a country annually starting with 2004.

Allen, Qian, and Qian (2005) discuss several dimensions of China's legal and regulatory environment and compare to countries that are included in the La Porta et al (1998) indexes. For one of the La Porta et al (1998) series that we use, anti-director rights, Allen, Qian, and Qian (2005) estimate an index value of 3 for China while Pistor, Raiser, and Gelfer (2000)

${ }^{21}$ See, for example, http://www.milkeninstitute.org/pdf/CAI2009.pdf.

22 http://info.worldbank.org/governance/wgi/index.asp 
estimate an index value of 3.45 for Russia. We substitute these values into any tests than include the anti-director rights index. ${ }^{23}$ Some of the more detailed measures of the workings of the legal system may also not fully describe the environment in a less developed country. For example, Djankov et al (2003) reports values for the time it takes to collect on a bad check or evict a tenant for non-payment of rent, and their tables include China. However, checks are not as widely used in China as in other economies and evictions do not often involve formal legal proceedings. Measures of the ease of raising capital and adjudicating legal and regulatory problems are interpreted as if maximizing shareholder wealth is the primary goal of corporations. Finally, the environment perceived by investors and the measures tabulated by these sources can depend on whether the investor is a local or a foreigner. The apparent success of China's economy in the absence of a high quality legal and regulatory environment raises concerns about the research efficacy of any such measures (Allen, Qian, and Zhang, 2011). Thus, there are limitations to the usefulness of these indicators, particularly as they apply to one of our most interesting and important home countries, China.

\subsection{Methodology}

23 Alternatively, we can consider China as the base case reflected in our regression intercepts. 
To test our hypotheses from Section 3.1, we begin with several test specifications inspired by Doidge, Karolyi, and Stulz (2004). We regress Tobin's $q$ on firm and home country characteristics and an OFC dummy variable:

$$
\mathrm{q}_{\mathrm{it}}=\alpha_{0}+\alpha_{1} \mathrm{D}_{\mathrm{ofc}, \mathrm{it}}+\boldsymbol{\beta}^{\prime} \mathbf{x}_{\mathbf{i t}}+\boldsymbol{\delta}^{\prime} \mathbf{c}_{\mathbf{i t}}+\varepsilon_{\mathrm{it}}
$$

$\mathrm{D}_{\text {ofc,it }}$ is the OFC dummy equal to one if firm $\mathrm{i}$ is incorporated in an OFC in year t. $\mathbf{x}_{\mathbf{i t}}$ is a vector of company characteristics, and $\mathbf{c}_{\mathbf{i t}}$ is a vector of country characteristics. The observations are firm-years for two types of firms. Sample firms are those located in a non OFC country but incorporated in an OFC country, such as a US firm incorporated in the Cayman Islands. In addition, our OFC sample also includes a small number of firms located in an OFC country but incorporated in a different OFC country. Control firms are both located and incorporated in non OFC countries. Firms which are both located and incorporated in an OFC are excluded. This excludes the relatively large number of firms that are both located and incorporated in Hong Kong, Ireland, Singapore, and Switzerland.

An extension of (8) is a two-stage Heckit procedure to control for a specific self-selection issue. The classic "treatment effects" problem for (8) is that an apparent relationship between individual firm Tobin's $q$ and incorporation in an OFC can induced by the decision about where to incorporate, rather than from OFC incorporation itself. The effect is akin to that of an 
omitted variable in (8) if the decision to incorporate, $\mathrm{D}_{\mathrm{ofc}, \mathrm{it}}$, is a function of firm characteristics, $\mathbf{x}_{\mathbf{i t}}$, and country characteristics, $\mathbf{c}_{\mathbf{i t}}$, and the error terms in (8) and the selection equation (which explains the unobserved value driving $\mathrm{D}_{\text {ofc,it }}$ ) are correlated. Therefore, we estimate a two-stage procedure following Doidge, Karolyi, and Stulz (2004) and Bailey, Karolyi, and Salva (2006). The first stage is a Probit regression to identify factors that predict whether a firm chooses to incorporate in an OFC. The dependent variable is the OFC dummy. The independent variables are country and firm characteristics. The second stage regresses firm-specific Tobin's $q$ on the OFC dummy variable and country and firm characteristics as in (8), plus the inverse Mills ratio from the first stage.

As an alternative to the Heckit procedure, we can think of (8) as suffering from an endogenous variable, $\mathrm{D}_{\mathrm{ofc}, \mathrm{it}}$, among its explanatory variables. Therefore, we also estimate a two-stage least-squares (2SLS) version of (8).

Another single-stage variation on (8) adds slope dummy terms equal to the explanatory variables times the OFC dummy. This decomposes the OFC valuation discount or premium measured by the slope, $\alpha_{1}$, on the OFC dummy in (8).

Next, we follow Doidge, Karolyi, and Stulz (2007) and regress firm governance and disclosure quality measures on other firm characteristics, home country characteristics, and OFC dummy variable in a specification similar to (8): 


$$
\mathrm{y}_{\mathrm{it}}=\alpha_{0}+\alpha_{1} \mathrm{D}_{\mathrm{ofc}, \mathrm{it}}+\boldsymbol{\beta}^{\prime} \mathbf{x}_{\mathbf{i t}}+\boldsymbol{\delta}^{\prime} \mathbf{c}_{\mathbf{i t}}+\varepsilon_{\mathrm{it}}
$$

$y_{i t}$ represents a firm specific governance or disclosure characteristic. If governance and disclosure measures are just cross-section or do not vary significantly over time, then this regression must be purely cross sectional. Else it can be estimated as a pooled regression. There may be some firm specific governance measures (such as the concentration of ownership from Datastream) that vary over time. Variations on (9) include the two-stage Heckit, two stage least squares, and the slope dummies specification described above for (8).

If we find at least a few dozen firms which experience an OFC event, that is, either moving incorporation to or from an OFC, we can conduct an event study following Bailey, Karolyi, and Salva (2006). Regressions similar to (8) and (9) as described above also include the OFC incorporation dummy to distinguish firm-years when the firm was incorporated in an OFC from other firm-years.

Finally, we follow the empirical initial public offerings literature and study IPO performance, and relate this to offering, firm, and incorporation country characteristics. ${ }^{24}$ For a first look at IPOs for this draft of the paper, we focus on firms from China only, given the interest and controversy surrounding them.

\section{Empirical results and discussion}

${ }^{24}$ See, for example, Welch (1991) for a cross sectional regression approach. 


\subsection{An overview of the data}

Table 1 tabulates country of incorporation, country of address, and listing exchange for the firms in the OFC sample. Panel A includes an observation for each pair of firm and listing exchange (2397 total). This means that a firm with two listings on two different exchanges counts twice. On the other hand, Panel B includes an observation for each distinct firm only (1372 total). Comparison of the two panels suggests how many of the OFC-incorporated firms are listed in more than one market.

Across Panels A and B of Table 1, it is evident that country of incorporation is heavily concentrated in two jurisdictions, Bermuda and the Cayman Islands, which account for over $75 \%$ of the sample firms. The British Virgin Islands is a distant third, with less than $5 \%$ of the OFC sample firms. Among the home countries for these OFC incorporated firms, Hong Kong firms account for more than half of the OFC sample, Chinese firms about a fifth, and UK and USA firms each less than 10\% of other OFC sample firms. Most Hong Kong address firms are incorporated in Bermuda while most China address firms are incorporated in the Cayman Islands. Most UK address firms incorporate in the nearby British Crown Dependencies Jersey, Isle of Man, and Guernsey. Interestingly, Greek firms are most likely to incorporate in the Marshall Islands, where they are the most frequent address country. ${ }^{25}$ These findings suggest

25 The Marshall Islands specialized in special provisions for the incorporation of maritime shipping companies. 
that certain jurisdictions may cater to the needs of firms from specific home countries or perhaps even particular industries.

Panels C and D of Table 1 summarize the exchanges where our sample firms are listed. We note several prominent patterns in these two panels. First, listing on formal US exchanges (Panel C) is unusual except for Chinese firms incorporated in the Cayman Islands and, to a lesser degree, the British Virgin Islands. Panel D indicates several hundred firms headquartered in Hong Kong but incorporated in Bermuda or the Cayman Islands are also listed in Hong Kong. Most unexpected is the huge number of Hong Kong and China address firms which are OFC incorporated and listed on Germany's Berlin or Frankfurt stock exchanges.

Panel A of Table 2 reports averages of Tobin's $q$ broken down by country of incorporation and country of address. Note that the sample size is smaller than in Table 1 as all firms with total assets less than ten million US dollars are excluded to avoid problems computing Tobin's q. Substantial differences across the rows and columns are evident. Hong Kong firms that incorporate in an OFC have higher $q$ than control firms, except for those that incorporate in the British Virgin Islands, which display an extremely low average $q$ of 0.4783 . In contrast, OFC incorporated Chinese firms typically have lower $q$ than control Chinese firms, with a particularly low average, 0.4434 , for firms incorporated in the British Virgin Islands. Low $q$ for UK and US firms incorporated in the British Virgin Islands are also evident, though the contrast is not as great as for Hong Kong and China address firms and the numbers of UK and 
US firms are much lower than for Hong Kong and China. The gap between OFC sample and control sample $q$ is also much less stark for UK and US firms. ${ }^{26}$

Panel B of Table 2 summarizes other firm characteristics. Relative to control firms, OFC incorporated firms have lower average sales growth. This is consistent with H1a which predicts that OFC incorporation is more likely for firms with lower growth opportunities. Firm size as measured by log of USD sales is similar across control and OFC incorporated groups, which combined with the finding of lower growth opportunities suggests "cash cows" are more likely to incorporate in an OFC. Leverage is smaller for Bermuda, British Virgin Islands, and Cayman Islands incorporated firms relative to control firms, but larger for firms incorporated in other OFCs.

\subsection{Regression estimates}

This section report results of cross section and time series regressions following Doidge, Karolyi, and Stulz (2004) and Bailey, Karolyi, and Salva (2006). Our dependent variables are Tobin's $q$ and, for firms that enter the sample as IPOs, IPO returns. Independent variables are characteristics of the firm and of its home country. For this draft of the paper, firm characteristics are a dummy set to 1 for firms incorporated in an OFC and three year sales growth. Country of address characteristics are selected to both cover the characteristics we

26 The Appendix includes Supplement to Table 2 which tables summary statistics on other country characteristic 
wish to measure and to overcome the lack of measures for some countries (particularly China) in some series.

Table 3 presents estimates of the single-stage regression, Equation (8), to explain yearly firm Tobin's $q$. Specification (1) includes only a constant and the OFC dummy, and we find a strong negative coefficient of $-0.0948(\mathrm{t}$-statistic $=-11.64)$ on the OFC dummy but a very small r-squared. This implies that firms incorporated in an OFC have a significantly lower Tobin's $q$ relative to counterparts incorporated domestically. This is consistent with $\mathrm{H} 1$, which predicts that OFC incorporation facilities managerial expropriation and reduces firm value. When we add year and industry fixed effects, specification (2), the coefficient on the OFC dummy becomes even more negative and statistically significant, -0.1241 (t-statistic $=-15.39)$, while the r-squared rises to over $11 \%$. Next we begin adding firm and country explanatory variables. Specification (3) includes only log Sales and the anti-director rights index. Both have positive and highly significant slope coefficients, indicating that Tobin's $q$ is typically higher for larger firms and firms from higher quality legal and regulatory environments. The OFC dummy remains significantly negative with the inclusion of these two variables.

Specification (4) adds four country-level characteristics similar to those found to be significant in Doidge, Karolyi, and Stulz (2004). With English law dummy, Milken Capital Access index, Check, Evict, WGI Regulatory Quality, and DB Disclosure, the coefficient on the OFC dummy remains negative, -0.0926 with a t-statistic of -10.61 . Most of the signs of 
slopes make sense: Tobin's $q$ is greater for firms from countries scoring high on access to capital, disclosure quality, speed of collecting on a check, and speed of evicting a tenant. However, negative signs suggest that Tobin's $q$ is lower for firms from English common law countries or countries that score high on Regulatory Quality.

A concern with these regressions is the potential for very large Tobin's $q$ (3.3039 in Panel B of Table 2) of Chinese control firms to tilt the regression estimates given the large number of control firms (457 of 8008) from China. Therefore, we offer three final specifications $(5,6$, and 7) which exclude China address firms. The anomalous negative slope on the English common law dummy weakens in (6) and vanishes in (7) while the negative slope on Regulatory Quality becomes positive in both (6) and (7). The negative slope coefficient on the OFC incorporation dummy remains highly significant and is slightly larger in scale. However, the sign on Miliken capital access index becomes negative. On balance, Table 3 suggests that firms from higher quality environments tend to have higher Tobin's $q$, but incorporation in an OFC detracts significantly from this.

While Table (3) shows substantially lower Tobin's $q$ for firms incorporated in OFCs, these single equation pooled regressions do not account for potential self-selection bias: firms choose whether or not to incorporate in an OFC. To correct for this, we estimate Heckit two stage regressions as previously described. The first-stage probit describes the decision to 
incorporate off-shore while the second stage includes the inverse Mills Ratio to control for self-selection and measure the additional effect of OFC incorporation on Tobin's $q$.

Highlights of the estimates presented in Table 4 are as follows. First, the estimates of the Probit equation show that large firms (log Sales) and firms from high quality environments (anti director rights index) are significantly more likely to incorporate OFCs. Second, the second stage of the Heckit procedure shows that the negative association between OFC dummy and Tobin's $q$ is still significant even after controlling for treatment effects, even though the significant slope on the inverse Mill's ratio suggests that those effects are significant. Third, some of the country governance variables have coefficients in the second stage regression that make sense: Tobin's q is higher for firms from high quality environments (high anti director rights index, low value of days to Evict. Other coefficient signs seem counter-intuitive, such as negative slopes for English law dummy, though we note once again that the presence of many Chinese control firms with high Tobin's $q$ can cause this finding. Finally, the most prominent element of the 2SLS estimate is that the slope coefficient on OFC dummy becomes statistically insignificant. The r-squared from 2SLS is smaller than that from the second stage of the Heckit procedure.

Table 5 decomposes the significantly negative slope on OFC dummy found in Table 3 and in the second pass of the Heckit procedure in Table 4. Specifically, each explanatory variable is also used to generate an interactive term, its product with the OFC dummy. The strongly 
positive slope, $0.0371(\mathrm{t}$ test $=8.72)$ for the $\log$ Sales interactive means that the negative association between Tobin's q and OFC dummy is weaker for larger firms. This weakening of the negative value effect of OFC incorporation is also observed for firms from high quality environments as measured by the anti-director rights index, Evict, and the regulatory quality index. Negative slopes for the English law dummy and disclosure index dummy and a positive slope for Check indicate that higher quality environment is associated with a deepening negative association of value with OFC listing. We can offer several tentative explanations for this. First, the effect can simply represent multicolinearity among the country quality variables and their interaction effects. Second, the effect of very large average Tobin's $q$ for control firms from China (a non-English law jurisdiction which scores low on disclosure quality) can reverse the expected signs of coefficients. Finally, we offer the intriguing idea that when a firm from an environment that scores high in quality on some dimensions nonetheless chooses to incorporate in an OFC, it signals a weak or poorly managed firm seeking a more relaxed environment for managers and insiders to expropriate shareholder wealth.

\subsection{Event study of reincorporation events}

Some of our testable hypotheses (H1b, H2b) make predictions about the effect of a change in country of incorporation. Therefore, we construct an additional sample of firms that 
switched incorporation from their country of address to an offshore financial center. We offer some very preliminary summary statistics to suggest the effect of this switch on value. In Table 6 we present some very preliminary evidence that suggests how value changes around reincorporation in an OFC. First, it is evident that the number of such events is small, slightly more than 100 . Second, we see that there is enormous variation in Tobin's $q$, indicating very volatile book values from year to year. If we include only firms with positive book value of equity, ${ }^{27}$ mean Tobin's $q$ for all reincorporating firms in OFC jurisdictions decline from 2.65 two years before the reincorporation to 1.25 two years after.

We also present statistics for reincorporation in the three most popular OFC jurisdictions. It is difficult to draw conclusions given the small number of observations in each, but there is no clear evidence that reincorporation in an $\mathrm{OFC}$ is associated with increasing value as measured by Tobin's $q$.

\subsection{OFC Incorporation and initial public offerings of Chinese firms}

As discussed above, another facet of firm value can be observed by comparing the price of an initial public offering to its market price once it begins trading. For this draft of the paper, we briefly examine some statistics on IPOs of China-address firms for a first look at associations between firm value and incorporation in an OFC. In subsequent drafts, we will

${ }^{27}$ See Brown, Lajbcygier, and Li (2008) for the difficulties that negative book value of equity firms pose for researchers. The table indicates a small number of such firm-years in our sample. 
expand the sample of IPOs to all countries, in particular to make full use of the range of country characteristics that are available to us and can help confirm or reject some of our testable hypotheses.

Table 7 is based on data downloaded from the common stock offerings database of SDC. Panel A presents summary statistics on the limited number of variables which we could find for most IPOs from China. Across all China IPOs in the sample, the median one day and 90 day returns after the offering are close to zero while the median one year return is $-20 \%$. These numbers range very widely with instances of nearly complete losses after a year and gains of 100 or 1000 times. Comparing three major OFCs, Bermuda incorporated firms tend to experience the best (or least worst) IPO returns while British Virgin Island incorporations are weakest. British Virgin Island offerings are particularly small, incur larger underwriting expenses, and use fewer lead managers. Interestingly, British Virgin Island IPOs retain the largest fraction of insider ownership after the offering. Panel B shows that there are few significant correlations between IPO returns and offering characteristics.

\subsection{Agenda for revision of the paper}

Our first goal for revising the paper is to study indicators of firm quality beyond Tobin's $q$.

Standard and Poor's Transparency International provides a cross section of many governance and disclosure quality indicators and an overall index for some firms as of 2000 and is used in 
Doidge, Karolyi, and Stulz (2007). Aggarwal, Erel, Ferreira, and Matos (2011) create an annual 2004 to 2008 index of 41 firm-level governance measures. The underlying series are from RiskMetrics and are detailed in Aggarwal, Erel, Stulz, and Williamson (2009). We have access to these series but the coverage of our sample firms is poor, particularly firms from China. We will use sources like Worldscope, Mergent Online, and SDC to construct measures of concentrated ownership and control following Ayyagari and Doidge (2010) and Liao (2011). We will also measure disclosure environment for each firm-year with information from $\mathrm{I} / \mathrm{B} / \mathrm{E} / \mathrm{S}$, specifically, the number of analysts providing forecasts, the standard deviation of those forecasts, and the absolute value of the percent earnings surprise.

Second, we will collect or create more detailed country characteristics (legal and regulatory environment, benefits to incorporation) for each OFC. If we find substantial changes in particular OFC's laws and regulations, they may be treated as an exogenous break in regressions.

Third, we will measure the frequency of lawsuits and legal and regulatory action in US, UK, and other developed capital markets for our OFC incorporated firms and the control firms. The extent to which troubled firms are attracted to OFCs is an interesting additional dimension to our research question.

Finally, several additions will enhance our regression analysis. For example, we will compute global industry $q$ to follow previous authors. Additional firm characteristics such as 
financial ratios, capital expenditures and use of external capital markets (proxies for growth), and cross listing dummy variables allow us to characterize the firms we study more thoroughly. Finally, CEO characteristics can contribute to explaining the decision to incorporate or reincorporate in an OFC.

\section{Summary and conclusions}

This paper examines an interesting variation on the types of choices corporations make concerning their legal, regulatory, and disclosure environment. Offshore financial centers present both the hope of a more efficient, low cost legal home and the fear of a poorly-regulated environment that benefits managers and other insiders at the expense of ordinary shareholders. Our very preliminary results come down more on the side of offshore financial centers enabling managers and insiders to enjoy private benefits of control, rather than validating OFCs as useful competitors to large established jurisdictions. We hope to refine our findings with more data and analysis in forthcoming revisions. 


\section{References}

Aggarwal, R., Erel, I., Ferreira, M., and Matos, P., 2011, Does Governance Travel Around the World? Evidence from Institutional Investors, Journal of Financial Economics 100, 154 - 182.

Aggarwal, R., Erel, I., Stulz, R., Williamson, R., 2009, Differences in governance practices between U.S. and foreign firms: measurement, causes, and consequences, Review of Financial Studies 22, 31313169.

Allen, Franklin, and Faulhaber, Gerald R., 1989, Signalling by underpricing in the IPO market, Journal of Financial Economics 23, 303 - 323,

Allen, Franklin, Qian, Jun, and Meijun Qian, 2005, Law, finance, and economic growth in China, Journal of Financial Economics 77, 57 - 116.

Allen, Franklin, Qian, Jun "QJ", and Zhang, Chenying, 2011, An Alternative View on Law, Institutions, Finance and Growth, unpublished Boston College and University of Pennsylvania working paper (June).

Ang, James S., Jiang, Zhiqian, and Wu, Chaopeng, 2012, Good Apples, Bad Apples: Sorting Among Chinese Companies Traded in the US, unpublished Florida State University working paper.

Ayyagari, M., and Doidge, C., 2010, Does Cross-listing Facilitate Changes in Corporate Ownership and Control?, Journal of Banking and Finance 34, 208 - 223.

Bailey, Warren, Karolyi, G. Andrew, and Salva, Carolina, 2006, The Economic Consequences of Increased Disclosure: Evidence from International Cross-Listings, Journal of Financial Economics 81, 175-213. 
Bar-Gill, Oren, Barzuza Michal, and Bebchuk, Lucian, 2006, The Market for Corporate Law, Journal of Institutional and Theoretical Economics 162, $134-171$.

Bebchuk, Lucian A. and Cohen, Alma, 2003, Firms' Decisions Where to Incorporate, 46 The Journal of Law and Economics 46, 383 - 485.

Brown, Stephen, Lajbcygier, Paul, and Li, Bob, 2008, Going Negative: What to Do with Negative Book Equity Stocks, Journal of Portfolio Management 35, 95 - 102.

Comment, Robert, and Schwert, G. William, 1995, Poison or placebo? Evidence on the deterrence and wealth effects of modern antitakeover measures, Journal of Financial Economics 39, 3-43.

Daines, Robert M., 2001, Does Delaware Law Improve Firm Value?, Journal of Financial Economics 62, $525-558$.

Darrough, Masako N., Huang, Rong and Zhao, Sha, 2012, The Spillover Effect of Chinese Reverse Merger Frauds: Chinese or Reverse Merger?. Unpublished Baruch College working paper available at SSRN: http://ssrn.com/abstract $=2144483$

Desai, Mihir A., Foley, C. Fritz, and Hines, James R. Jr., 2006, The Demand for Tax Havens, Journal of Public Economics 90, 513-531.

Desai, M. A., and J. R. Hines, 2002, Expectations and expatriations: Tracing the causes and consequences of corporate inversions, National Tax Journal 55, 409 - 440. 
Djankov, S., LaPorta, R., Lopez-de-Silanes, F., and Shleifer, A., 2003, Courts, Quarterly Journal of Economics 118, 453-517.

Djankov, S., La Porta, R., Lopez-de-Silanes, F., and Shleifer, A., 2008, The Law and Economics of Self-Dealing, Journal of Financial Economics 88, 430 - 465.

Doidge, Craig, Karolyi, G. Andrew, and Stulz, René M., 2004, Why are foreign firms listed in the U.S. worth more? Journal of Financial Economics 71, 205-238.

Doidge, Craig, Karolyi, G. Andrew, and Stulz, René M., 2007, Why do countries matter so much for corporate governance?, Journal of Financial Economics 86, 1-39.

Doidge, Craig; Karolyi, Andrew; Stulz, René M., 2010, Why Do Foreign Firms Leave U.S. Equity Markets?, Journal of Finance 65, 1507-1553.

Durnev, Art, Li, Tiemei, and Magnan, Michel, 2011, Beyond Tax Avoidance: Offshore Firms, Institutional Environment, and Financial Reporting, unpublished University of Iowa working paper.

Durnev, Art, Li, Tiemei, and Magnan, Michel, 2012, Are Offshore Firms Worth More?, unpublished University of Iowa working paper.

Dyreng, Scott, and Lindsey, Bradley P., 2009, Using Financial Accounting Data to Examine the Effect of Foreign Operations Located in Tax Havens and Other Countries on US Multinational Firms' Tax Rates, Journal of Accounting Research 47, 1283 - 1316.

Fernandes, Nuno, Lel, Ugur, and Miller, Darius, 2010, Escape from New York: The Market Impact of Loosening Disclosure Requirements, Journal of Financial Economics 95, 129-147. 
Givoly, Dan, Hayn, Carla, and Lourie, Ben, 2012, Importing Accounting Quality: The Case of Foreign

Reverse Mergers, unpublished Pennsylvania State University and University of California, Los Angeles working paper (May).

Grinblatt, Mark, and Hwang, Chuan Yang, 1989, Signaling and the Pricing of New Issues, Journal of Finance $44,393-420$.

Hines, Jr., James R., and Rice, Eric M., 1994, Fiscal Paradise: Foreign Tax Havens and American Business, Quarterly Journal of Economics 109, 149-182.

Hughes, P. J., and Thakor, A. V., 1992, Litigation risk, intermediation, and the underpricing of initial public offerings, Review of Financial Studies 5, $709-742$.

Hung, Mingyi, Wong, T. J., and Zhang, Fang, 2011, The Value of Relationship-based and Market-based Contracting: Evidence from Corporate Scandals in China, unpublished Chinese University of Hong Kong working paper (May).

International Monetary Fund, 2006, Offshore Financial Centers: The Assessment Program-A Progress Report, Monetary and Financial Systems Department (February).

International Monetary Fund, 2008, Offshore Financial Centers: A Report on the Assessment Program and Proposal for Integration with the Financial Sector Assessment Program, Monetary and Capital Markets Department and the Legal Department (May).

Jindra, Jan, Voetmann, Torben and Walkling, Ralph A., 2012, Reverse Mergers: The Chinese Experience, unpublished Drexel University working paper. Available at SSRN: http://ssrn.com/abstract=2105814. 
La Porta, R., Lopez-de-Silanes, F., Shleifer, A., Vishny, R., 1998, Law and finance, Journal of Political Economy 106, 1113-1155.

Lane, Philip R., and Milesi-Ferretti, Gian M., 2010, Cross-Border Investment in Small International Financial Centers, IMF Working paper 10/38.

Liao, Rose C., 2011, What drives corporate block acquisitions? The case for financial constraints, unpublished Rutgers University working paper.

Malatesta, Paul H, and Walkling, Ralph A., 1988, Poison Pill Securities: Stockholder Wealth, Profitability, and Ownership Structure, Journal of Financial Economics 20, 347-376.

Morriss, Andrew P., ed., 2010, Offshore Financial Centers and Regulatory Competition, Washington, DC: The AEI Press.

The New York Times, 2012, F.B.I. Looks Into Adviser on Chinese Reverse Mergers - NYTimes.com http://dealbook.nytimes.com/2012/01/27.

Pistor, K., Raiser, M., and Gelfer, S., 2000, Law and finance in transition economies, The Economics of Transition $8,325-368$.

Public Company Accounting Oversight Board (PCAOB), 2011, Activity Summary and Audit Implications for Reverse Mergers1 Involving Companies from the China Region: January 1, 2007 through March 31, 2010, Research Note \# 2011-P1

Shaxson, Nicholas, 2011, Treasure Islands: Uncovering the Damage of Offshore Banking and Tax Havens, New York: Palgrave MacMillian. 
Spamann, Holger, 2010, The “Antidirector Rights Index” Revisited, Review of Financial Studies 23, 467-486.

Subramanian, Guhan, 2004, The Disappearing Delaware Effect, Journal of Law, Economics \& Organization $20,32-59$.

Suss, Esther C., Williams, Oral, and Mendis, Chandima, 2002, Caribbean Offshore Financial Centers: Past, Present, and Possibilities for the Future, IMF Working Paper 02/88.

Tinic, S., 1988, Anatomy of Initial Public Offerings of Common Stock, Journal of Finance 43, 789 - 822. United States. Securities and Exchange Commission, 2011, Reverse Mergers, Investor Bulletin ( $9^{\text {th }}$ June). van der Does de Willebois, Emile, Halter, Emily M., Harrison, Robert A., Park, Ji Won, and Sharman, J. C., 2011, The Puppet Masters: How the Corrupt Use Legal Structures to Hide Stolen Assets and What to Do About It, World Bank Stolen Asset Recovery Initiative report.

Wald, John K., and Long, Michael S., 2007, The Effect of State Laws on Capital Structure, Journal of Financial Economics, 83, 297 - 320.

Welch, Ivo, 1989, Seasoned Offerings, Imitation Costs, and the Underpricing of Initial Public Offerings, Journal of Finance 44, 421 - 449.

Welch, Ivo, 1991, An Empirical Examination of Models of Contract Choice in Initial Public Offerings, Journal of Financial and Quantitative Analysis 26, 497 - 518.

Zoromé, Ahmed, 2007, Concept of Offshore Financial Centers: In Search of an Operational Definition, IMF Working Paper 07/87. 


\section{Table 1. The distribution of country of incorporation, country of address, and exchange listing for sample firms}

This table summarizes the country of incorporation and country of address of sample firms. Panel A tabulates sample firms by each stock exchange listing (unique ISIN number and exchange). Panel B tabulates sample firms without double-counting cross listings. The extent of cross listing can be inferred by comparing the two panels. The supplement to Table 1 Panel B (at the end of the paper) details the distribution of sample firms for countries of incorporation or countries of average classified as "Others" in

Panel B. Sample firms are incorporated in an OFC but with address not in an OFC as identified from Datastream, www.adr.com, Worldscope, or CompustatNA.

Panel A: Unique firms and exchange listings

Country of Incorporation

\begin{tabular}{|c|c|c|c|c|c|c|c|c|c|c|c|c|c|}
\hline & & & British & & & & & & & & & & \\
\hline Address & & Cayman & Virgin & & Marshall & Isle of & & Netherlands & & & & & \\
\hline Country & Bermuda & Islands & Islands & Jersey & Islands & Man & Guernsey & Antilles & Cyprus & Bahamas & Panama & Others & Total \\
\hline Hong Kong & 758 & 504 & 13 & 0 & 3 & 0 & 0 & 0 & 0 & 0 & 0 & 2 & 1280 \\
\hline China & 65 & 362 & 24 & 1 & 0 & 2 & 0 & 0 & 0 & 0 & 0 & 4 & 458 \\
\hline UK & 16 & 5 & 42 & 56 & 1 & 56 & 24 & 0 & 7 & 0 & 0 & 15 & 222 \\
\hline USA & 39 & 16 & 7 & 0 & 20 & 0 & 0 & 9 & 0 & 6 & 9 & 6 & 112 \\
\hline Singapore & 53 & 3 & 0 & 0 & 0 & 0 & 0 & 1 & 0 & 0 & 0 & 0 & 57 \\
\hline Canada & 11 & 13 & 13 & 5 & 1 & 0 & 0 & 0 & 0 & 4 & 0 & 1 & 48 \\
\hline Greece & 2 & 1 & 0 & 2 & 40 & 0 & 0 & 0 & 0 & 0 & 0 & 0 & 45 \\
\hline Norway & 15 & 3 & 0 & 0 & 0 & 0 & 0 & 0 & 11 & 0 & 0 & 5 & 34 \\
\hline Others & 45 & 16 & 10 & 12 & 9 & 6 & 8 & 12 & 3 & 4 & 3 & 13 & 141 \\
\hline Total & 1004 & 923 & 109 & 76 & 74 & 64 & 32 & 22 & 21 & 14 & 12 & 46 & 2397 \\
\hline
\end{tabular}


Table 1 continued.

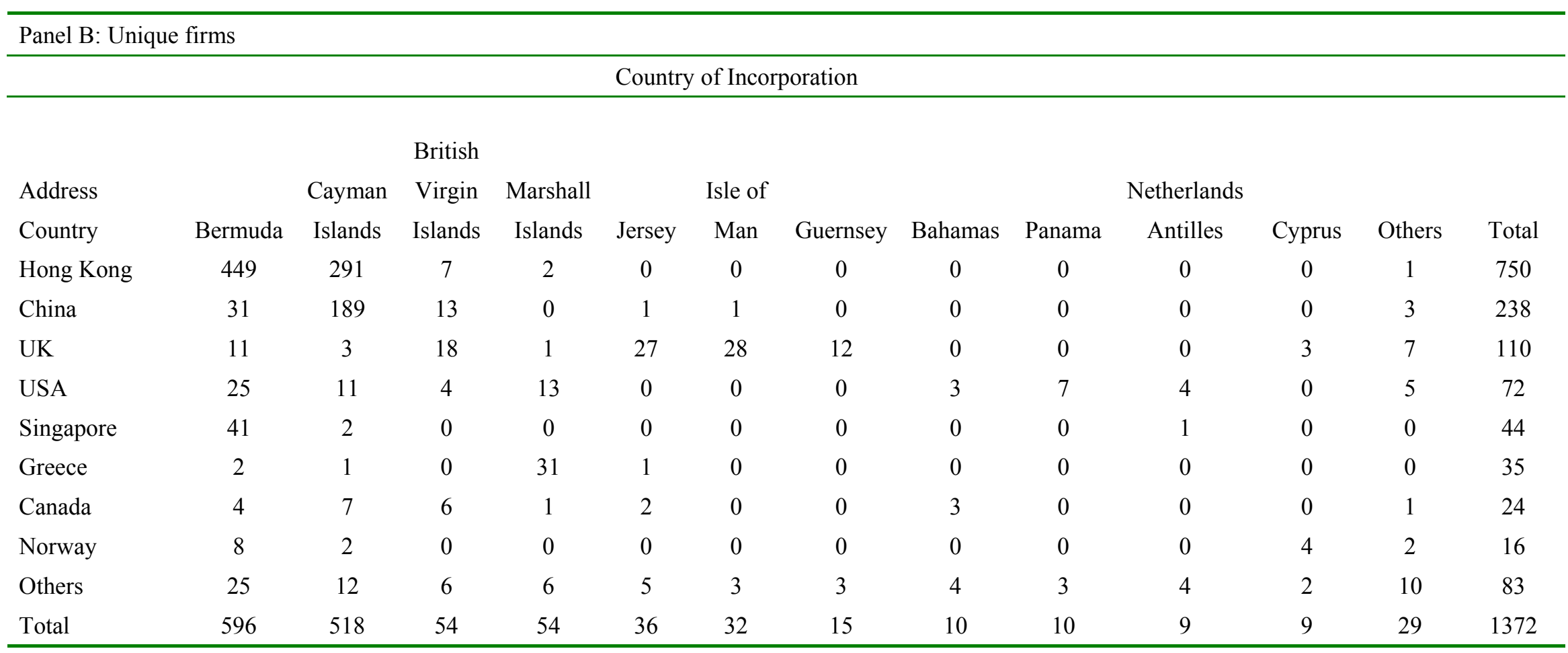




\section{Table 1 continued.}

\begin{tabular}{|c|c|c|c|c|c|}
\hline \multicolumn{6}{|c|}{ Panel C: Listings on US exchanges } \\
\hline \multirow[b]{2}{*}{ Exchange } & \multicolumn{5}{|c|}{ Country of Incorporation } \\
\hline & Country of address & Bermuda & Cayman Islands & British Virgin Islands & Other \\
\hline \multirow[t]{5}{*}{ NYSE/Amex } & Hong Kong & 1 & 1 & 0 & 1 \\
\hline & China & 0 & 19 & 2 & 3 \\
\hline & UK & 1 & 0 & 0 & 2 \\
\hline & US & 6 & 3 & 0 & 10 \\
\hline & Other & 5 & 0 & 0 & 19 \\
\hline \multirow[t]{5}{*}{ NASDAQ } & Hong Kong & 3 & 2 & 2 & 7 \\
\hline & China & 0 & 38 & 4 & 2 \\
\hline & UK & 1 & 0 & 0 & 1 \\
\hline & US & 3 & 2 & 0 & 4 \\
\hline & Other & 3 & 3 & 0 & 24 \\
\hline \multirow[t]{5}{*}{ Over the counter } & Hong Kong & 10 & 8 & 0 & 0 \\
\hline & China & 0 & 10 & 0 & 0 \\
\hline & UK & 0 & 0 & 0 & 1 \\
\hline & US & 5 & 1 & 3 & 6 \\
\hline & Other & 9 & 5 & 2 & 23 \\
\hline
\end{tabular}




\section{Table 1 continued.}

\begin{tabular}{|c|c|c|c|c|c|}
\hline \multicolumn{6}{|c|}{ Panel D: Listings on non US exchanges } \\
\hline \multirow[b]{2}{*}{ Exchange } & \multicolumn{5}{|c|}{ Country of Incorporation } \\
\hline & Country of address & Bermuda & Cayman Islands & British Virgin Islands & Other \\
\hline \multirow{3}{*}{ London } & China & 0 & 2 & 0 & 1 \\
\hline & UK & 8 & 3 & 4 & 18 \\
\hline & US & 0 & 0 & 0 & 0 \\
\hline \multirow[t]{5}{*}{ Hong Kong } & Hong Kong & 273 & 174 & 1 & 2 \\
\hline & China & 4 & 6 & 0 & 0 \\
\hline & UK & 0 & 0 & 0 & 0 \\
\hline & US & 0 & 0 & 0 & 0 \\
\hline & Other & 0 & 0 & 0 & 0 \\
\hline \multirow{2}{*}{ Berlin } & US & 2 & 0 & 0 & 2 \\
\hline & Other & 7 & 2 & 3 & 18 \\
\hline \multirow[t]{5}{*}{ Frankfurt } & Hong Kong & 333 & 228 & 7 & 2 \\
\hline & China & 30 & 213 & 12 & 0 \\
\hline & UK & 0 & 2 & 16 & 73 \\
\hline & US & 23 & 9 & 4 & 20 \\
\hline & Other & 46 & 17 & 13 & 132 \\
\hline
\end{tabular}




\section{Table 2. Summary statistics on individual company characteristics}

Sample firms are incorporated in an OFC but with address not in an OFC as identified from Datastream, www.adr.com, Worldscope, or CompustatNA. Their financials are collected from Datastream and CompustatNA. Control firms have Datastream country of address in one of the countries of address in the OFC-incorporated sample but are not incorporated in an OFC and have assets greater than USD 10 million. For each firm, Tobin's $q$ is averaged across firm-years, and the table in turn averages across firms.

\section{Panel A: Tobin's $q$}

\begin{tabular}{|c|c|c|c|c|c|c|c|c|c|c|c|c|c|c|}
\hline \multirow[b]{4}{*}{ Address } & & & \multicolumn{12}{|c|}{ Country of Incorporation } \\
\hline & \multicolumn{2}{|c|}{ Control } & \multicolumn{3}{|c|}{$\underline{\text { Bermuda }}$} & \multicolumn{3}{|c|}{$\underline{\text { Cayman Islands }}$} & \multicolumn{3}{|c|}{$\underline{\text { British Virgin Islands }}$} & \multicolumn{3}{|c|}{$\underline{\text { Others }}$} \\
\hline & \multirow[b]{2}{*}{$\#$ of } & \multicolumn{2}{|l|}{ Average } & \multicolumn{2}{|l|}{ Average } & \multicolumn{3}{|c|}{ Average } & \multicolumn{3}{|c|}{ Average } & \multicolumn{3}{|c|}{ Average } \\
\hline & & Tobin's & $\#$ of & Tobin's & Diff with & \# of & Tobin's & Diff with & $\#$ of & Tobin's & Diff with & \# of & Tobin's & Diff with \\
\hline Country & Firms & Q & Firms & Q & Control & Firms & Q & Control & Firms & Q & Control & Firms & Q & Control \\
\hline Hong Kong & 75 & 0.8893 & 352 & 1.1360 & -0.2467 & 197 & 1.4923 & -0.6030 & 7 & 0.4783 & 0.4110 & 2 & 0.9818 & -0.0924 \\
\hline China & 457 & 3.3039 & 25 & 0.8410 & 2.4629 & 123 & 1.8230 & 1.4809 & 11 & 0.4434 & 2.8604 & 2 & 0.5399 & 2.7640 \\
\hline UK & 629 & 1.3835 & 6 & 1.1998 & 0.1838 & 1 & 1.9194 & -0.5359 & 7 & 1.0861 & 0.2974 & 47 & 1.6287 & -0.2452 \\
\hline US & 2592 & 1.3407 & 14 & 2.2159 & -0.8752 & 3 & 1.9195 & -0.5789 & 3 & 1.2408 & 0.0999 & 15 & 1.3813 & -0.0407 \\
\hline Singapore & 294 & 1.2448 & 13 & 2.0926 & -0.8478 & 1 & 1.0208 & 0.2241 & NA & NA & NA & NA & NA & NA \\
\hline Greece & 317 & 1.2134 & 3 & 1.6120 & -0.3986 & 3 & 1.0482 & 0.1652 & 4 & 0.9857 & 0.2277 & NA & NA & NA \\
\hline Canada & 79 & 1.2327 & 8 & 1.1185 & 0.1142 & 2 & 1.3395 & -0.1069 & NA & NA & NA & 5 & 4.5171 & -3.2844 \\
\hline Norway & 141 & 1.5010 & 2 & 2.0732 & -0.5721 & NA & NA & NA & NA & NA & NA & 4 & 1.3048 & 0.1963 \\
\hline Netherlands & 259 & 1.2412 & 7 & 1.0066 & 0.2346 & NA & NA & NA & NA & NA & NA & 1 & 1.4835 & -0.2422 \\
\hline Others & 3165 & 1.3196 & 8 & 1.3981 & -0.0785 & 6 & 0.6624 & 0.6572 & 5 & 0.4503 & 0.8693 & 37 & 1.4573 & -0.1377 \\
\hline Total & 8008 & & 438 & & & 336 & & & 37 & & & 113 & & \\
\hline
\end{tabular}




\section{Table 2 continued.}

\section{Panel B: Other firm characteristics}

\begin{tabular}{|c|c|c|c|c|c|c|c|c|c|c|c|c|c|c|}
\hline & \multicolumn{14}{|c|}{ Country of Incorporation } \\
\hline & \multicolumn{2}{|c|}{$\underline{\text { Control }}$} & \multicolumn{3}{|c|}{$\underline{\text { Bermuda }}$} & \multicolumn{3}{|c|}{$\underline{\text { Cayman Islands }}$} & \multicolumn{3}{|c|}{$\underline{\text { British Virgin Islands }}$} & \multicolumn{3}{|c|}{ Other } \\
\hline & & & $\#$ of & & Diff with & $\#$ of & & Diff with & $\#$ of & & Diff with & $\#$ of & & Diff with \\
\hline & \# of Firms & Average & Firms & Average & Control & Firms & Average & Control & Firms & Average & Control & Firms & Average & Control \\
\hline \multicolumn{15}{|l|}{ Sales } \\
\hline Growth & 8008 & 1.8033 & 438 & 0.93575 & -0.8675 & 336 & 0.59828 & -1.205 & 37 & 0.3424 & -1.4609 & 113 & 0.66098 & -1.1423 \\
\hline \multicolumn{15}{|l|}{$\log$} \\
\hline \multicolumn{15}{|l|}{ Sales } \\
\hline USD & 8008 & 12.089 & 438 & 12.0066 & -0.0828 & 336 & 12.1368 & 0.04752 & 37 & 12.2 & 0.1107 & 113 & 11.8792 & -0.2101 \\
\hline \multicolumn{15}{|l|}{ Debt to } \\
\hline
\end{tabular}




\section{Table 3. Single-stage regressions to explain individual firm Tobin's $q$}

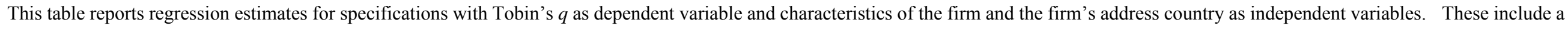

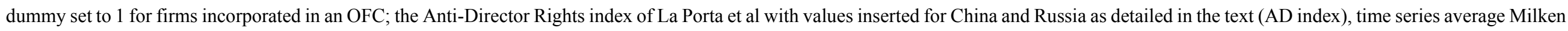

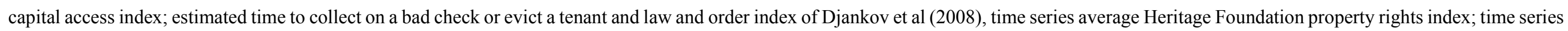

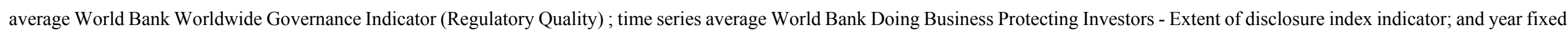
effects and industry (40 categories) fixed effects. Observations are firm-years. Variables Judicial Efficiency and Accounting Standards are not available for China

\begin{tabular}{|c|c|c|c|c|c|c|c|c|c|c|c|c|c|c|}
\hline & & & & & & & & & \multicolumn{6}{|c|}{ Exclude China address firms } \\
\hline & 1 & & 2 & & 3 & & 4 & & 5 & & 6 & & 7 & \\
\hline & slope & t-test & slope & t-test & slope & t-test & slope & t-test & Slope & t-test & slope & t-test & slope & t-test \\
\hline Intercept & 1.2834 & 557.15 & 1.3013 & 42.61 & 1.0543 & 28.7 & 1.0889 & 13.51 & 0.8279 & 23.57 & 1.1871 & 15.41 & 1.1673 & 13.41 \\
\hline OFC dummy & -0.0948 & -11.64 & -0.1241 & -15.39 & -0.1381 & -16.58 & -0.0926 & -10.61 & -0.1355 & -16.24 & -0.1331 & -14.03 & -0.2237 & -19.46 \\
\hline 3 year sales growth & - & - & - & - & - & - & - & - & - & - & - & - & $-1.2 \mathrm{E}-05$ & -0.47 \\
\hline $\log$ Sales & - & - & - & - & 0.0144 & 10.24 & 0.0142 & 10.03 & 0.0203 & 15.11 & 0.0191 & 14.05 & 0.0223 & 15.32 \\
\hline English law dummy & - & - & - & - & - & - & -0.1802 & -16.98 & - & - & -0.0297 & -2.76 & 0.0024 & 0.15 \\
\hline AD index & - & - & - & - & 0.0145 & 7.77 & 0.0202 & 4.91 & 0.0239 & 13.47 & 0.0304 & 7.71 & 0.0271 & 5.37 \\
\hline Milken capital index & - & - & - & - & - & - & 0.5697 & 4.77 & - & - & -0.4455 & -3.83 & 0.0243 & 0.16 \\
\hline Judicial Efficiency & - & - & - & - & - & - & - & - & - & - & - & - & -0.0063 & -1.3 \\
\hline Accounting Standards & - & - & - & - & - & - & - & - & - & - & - & - & -0.0055 & -7.65 \\
\hline Check & - & - & - & - & - & - & -0.0002 & -5.89 & - & - & -0.0003 & -10.82 & -0.0003 & -8.37 \\
\hline Evict & - & - & - & - & - & - & -0.0007 & -23.49 & - & - & -0.0001 & -3.20 & -0.0001 & -3.51 \\
\hline Regulatory Quality & - & - & - & - & - & - & -0.2202 & -23.49 & - & - & 0.0481 & 3.44 & 0.0500 & 3.07 \\
\hline Disclosure & - & - & - & - & - & - & 0.0071 & 5.29 & - & - & -0.0032 & -2.46 & 0.0027 & 1.64 \\
\hline Fixed effects & no & & yes & & yes & & yes & & Yes & & yes & & yes & \\
\hline Adj. R-squared & 0.002 & & 0.112 & & 0.116 & & 0.133 & & 0.1298 & & 0.1313 & & 0.1393 & \\
\hline Observations & 83081 & & 83081 & & 79477 & & 79477 & & 77876 & & 77876 & & 65979 & \\
\hline
\end{tabular}




\section{Table 4. Two-stage regressions to explain individual firm Tobin's $q$}

This table reports regression estimates for specifications with Tobin's $q$ as dependent variable and characteristics of the firm and the firm's address country as independent variables. These include a dummy set to 1 for firms incorporated in an OFC; the revised Anti-Director Rights index of Djankov et al (2008) with values inserted for China and Russia as detailed in the text (AD index), time series average Milken capital access index; estimated time to collect on a bad check or evict a tenant and law and order index of Djankov et al (2008), ; time series average World Bank Worldwide Governance Indicator (Regulatory Quality) ; time series average World Bank Doing Business Protecting Investors - Extent of disclosure index indicator; and year fixed effects and industry (40 categories) fixed effects. Observations are firm-years. In Heckman procedure, first stage dependent variable for Probit is OFC dummy while second stage dependent variable is Tobin's $q$. Each specification is run separately for each year and the table reports averages of resulting coefficients.

\begin{tabular}{|c|c|c|c|c|c|c|}
\hline & Probit & & Heckman & & 2SLS & \\
\hline & Slope & z-test & slope & t-test & Slope & t-test \\
\hline Intercept & -3.282 & -8.391 & -19.732 & -2.152 & 0.669 & 1.524 \\
\hline OFC dummy & - & - & -0.154 & -3.130 & -0.835 & 1.302 \\
\hline log Sales & 0.010 & 0.878 & 0.111 & 2.417 & 0.023 & 2.461 \\
\hline English law dummy & - & - & -0.069 & -2.275 & 0.023 & -1.765 \\
\hline AD index & 0.375 & 8.552 & 1.715 & 2.356 & -0.007 & -0.180 \\
\hline Milken capital index & - & - & 0.034 & 0.290 & 0.347 & 0.901 \\
\hline Check & - & - & 0.000 & -1.101 & 0.000 & 0.655 \\
\hline Evict & - & - & 0.000 & -1.975 & 0.000 & -2.986 \\
\hline Regulatory Quality & - & - & -0.129 & -2.064 & -0.134 & -2.260 \\
\hline Disclosure & - & - & 0.004 & 0.510 & -0.012 & -1.428 \\
\hline Inverse Mills's Ratio & - & - & 5.757 & 2.310 & & \\
\hline Fixed effects & - & - & yes & & yes & \\
\hline Pseudo R-squared & 0.062 & & & & & \\
\hline Adj. R-squared & & & 0.166 & & 0.095 & \\
\hline Observations & 3137 & & 3137 & & 3137 & \\
\hline
\end{tabular}




\section{Table 5. Single-stage regression to decompose OFC valuation premium or discount reflected in individual firm Tobin's $q$}

This table reports regression estimate for specification with Tobin's $q$ as dependent variable and characteristics of the firm and the firm's address country as independent variables. These include a dummy set to 1 for firms incorporated in an OFC; the revised Anti-Director Rights index of Djankov et al (2008) with values inserted for China and Russia as detailed in the text (AD index), time series average Milken capital access index; estimated time to collect on a bad check or evict a tenant and law and order index of Djankov et al (2008); time series average World Bank Worldwide Governance Indicator (Regulatory Quality) ; time series average World Bank Doing Business Protecting Investors - Extent of disclosure index indicator; and year fixed effects and industry (40 categories) fixed effects. Observations are firm-years.

\begin{tabular}{lcccc}
\hline Independent variable & \multicolumn{2}{c}{$\begin{array}{c}\text { Coefficient on independent } \\
\text { variable }\end{array}$} & \multicolumn{2}{c}{$\begin{array}{c}\text { Coefficient on independent variable } \\
\text { times OFC dummy }\end{array}$} \\
\hline & slope & t-test & Slope & t-test \\
Intercept & 1.1071 & 13.25 & - & - \\
OFC dummy & -1.0348 & -3.33 & - & - \\
log Sales & 0.0102 & 6.86 & 0.0371 & -3.72 \\
English law dummy & -0.2045 & -18.8 & -0.2853 & -3.12 \\
AD index & 0.0141 & 3.37 & 0.1336 & 4.18 \\
Milken capital index & 0.7619 & 6.14 & 0.1173 & 3.24 \\
Check & -0.0002 & -4.79 & 0.0009 & -2.04 \\
Evict & -0.0008 & -25.79 & -0.0004 & 3.88 \\
Regulatory Quality & -0.2766 & -20.24 & 0.2241 & -4.08 \\
Disclosure & 0.0090 & 6.54 & -0.0335 & \\
Fixed effects & Yes & & & \\
Adj. R-squared & 0.1362 & & & \\
Observations & 79477 & & & \\
\hline
\end{tabular}


Table 6. Tobin's $q$ and reincorporation from non OFC country to OFC country

This table summarizes the valuation of companies that moved incorporation to an OFC during the period 1990 to June 2012. "Year $\mathrm{t}$ " refers to $t$ years before or after the reincorporation. Book value of equity less than zero tends to inflation Tobin's $q$. Sources of data include Mergentonline and Datastream.

\begin{tabular}{|c|c|c|c|c|c|}
\hline OFC domicile & Year -2 & Year -1 & Year 0 & Year +1 & Year +2 \\
\hline \multicolumn{6}{|l|}{ All } \\
\hline Mean Tobin's q & 2.64 & 20.31 & 2.23 & 20.38 & 2.98 \\
\hline Median & 1.18 & 1.00 & 1.03 & 1.02 & 1.07 \\
\hline Minimum & 0.36 & -2.68 & -1.00 & -0.75 & 0.21 \\
\hline Maximum & 98.08 & 1870.62 & 110.05 & 2463.00 & 52.46 \\
\hline Observations & 82 & 98 & 120 & 129 & 132 \\
\hline Mean for book equity $>0$ & 2.65 & 1.16 & 1.27 & 1.18 & 1.25 \\
\hline Observations with book equity $<0$ & 3 & 5 & 6 & 9 & 9 \\
\hline \multicolumn{6}{|l|}{ Bermuda } \\
\hline Mean Tobin's q & 1.18 & 1.16 & 1.17 & 1.11 & 5.20 \\
\hline Median & 1.03 & 0.93 & 0.97 & 1.00 & 1.08 \\
\hline Minimum & 0.36 & -0.74 & 0.02 & -0.75 & 0.21 \\
\hline Maximum & 4.10 & 4.22 & 4.49 & 3.72 & 52.46 \\
\hline Observations & 17 & 21 & 25 & 34 & 36 \\
\hline Mean for book equity $>0$ & 1.18 & 1.16 & 1.17 & 1.11 & 1.06 \\
\hline Observations with book equity $<0$ & 0 & 0 & 0 & 0 & 3 \\
\hline \multicolumn{6}{|l|}{ British Virgin Islands } \\
\hline Mean Tobin's q & 49.97 & 374.27 & 27.72 & 492.95 & 0.48 \\
\hline Median & 49.97 & 0.83 & 0.92 & 0.67 & 0.33 \\
\hline Minimum & 1.86 & -2.68 & -1.00 & 0.18 & 0.29 \\
\hline Maximum & 98.08 & 1870.62 & 110.05 & 2463.00 & 0.98 \\
\hline Observations & 2 & 5 & 4 & 5 & 4 \\
\hline Mean for book equity $>0$ & 49.97 & 0.18 & -0.38 & 0.44 & 0.48 \\
\hline Observations with book equity $<0$ & 0 & 1 & 2 & 1 & 0 \\
\hline \multicolumn{6}{|l|}{ Cayman Islands } \\
\hline Mean Tobin's q & 0.51 & 0.51 & 0.40 & 0.38 & 0.36 \\
\hline Median & 0.51 & 0.51 & 0.40 & 0.38 & 0.36 \\
\hline Minimum & 0.39 & 0.35 & 0.24 & 0.15 & 0.23 \\
\hline Maximum & 0.62 & 0.68 & 0.55 & 0.61 & 0.49 \\
\hline Observations & 2 & 2 & 2 & 2 & 2 \\
\hline Mean for book equity $>0$ & 0.505157 & 0.5141377 & 0.397052 & 0.380423 & 0.3571353 \\
\hline Observations with book equity $<0$ & 0 & 0 & 0 & 0 & 0 \\
\hline
\end{tabular}




\section{Table 7. Comparison of Chinese IPOs incorporated in an OFC to other Chinese IPOs}

This table summarizes data on initial public offerings of firms identified with an address in China. Period is 1990 to June 2012. Source of offering data is SDC.

\begin{tabular}{|c|c|c|c|c|c|c|c|c|c|c|c|}
\hline \multicolumn{12}{|c|}{ Panel A: Medians and other statistics on offering characteristics } \\
\hline Domicile & $\begin{array}{l}\text { IPO return } 1 \\
\text { day }\end{array}$ & $\begin{array}{c}\text { IPO } \\
\text { return } \\
90 \text { days }\end{array}$ & $\begin{array}{c}\text { IPO } \\
\text { return } 1 \\
\text { year }\end{array}$ & $\begin{array}{l}\text { Proceeds } \\
\text { million } \\
\text { USD }\end{array}$ & $\begin{array}{l}\text { Expense } \\
\text { percent }\end{array}$ & $\begin{array}{l}\text { Over- } \\
\text { allotment } \\
\text { Percent }\end{array}$ & $\begin{array}{l}\text { Number of } \\
\text { lead } \\
\text { managers }\end{array}$ & $\begin{array}{l}\text { Lock-up } \\
\text { dummy }\end{array}$ & $\begin{array}{l}\text { Venture } \\
\text { capital } \\
\text { dummy }\end{array}$ & $\begin{array}{c}\text { Percent } \\
\text { insiders } \\
\text { before offer }\end{array}$ & $\begin{array}{c}\text { Percent } \\
\text { insiders after } \\
\text { offer }\end{array}$ \\
\hline All & 1.055 & 0 & -20 & 88.5625 & 3.19406 & 0 & 3 & 1 & 0 & 68.26 & 48.98 \\
\hline $1 \%$ & -21.88 & -62.86 & -91.43 & 1.706 & 0.58831 & 0 & 1 & 0 & 0 & 2 & 1.7 \\
\hline $99 \%$ & 353.85 & 259.93 & 531.82 & 3021.58 & 21.6767 & 16.472 & 11 & 1 & 1 & 100 & 78.6 \\
\hline Observations & 158 & 163 & 151 & 196 & 176 & 196 & 196 & 196 & 196 & 70 & 68 \\
\hline Bermuda & 1.195 & 3.265 & -11.175 & 86.41 & 3.05969 & 1.08 & 2.5 & 0.5 & 0 & 60.135 & 51.5 \\
\hline $1 \%$ & -7.95 & -62.5 & -82.95 & 8.69 & 1.62189 & 0 & 1 & 0 & 0 & 2 & 1.7 \\
\hline $99 \%$ & 59.03 & 143.06 & 83.33 & 271.8 & 8.8877 & 15 & 4 & 1 & 1 & 95 & 57.8 \\
\hline Observations & 12 & 12 & 12 & 12 & 7 & 12 & 12 & 12 & 12 & 4 & 3 \\
\hline British Virgin Islands & 0 & -0.83 & -34.29 & 12 & 5 & 0 & 2 & 1 & 0 & 84.51 & 62.25 \\
\hline $1 \%$ & -22.35 & -62.86 & -72.92 & 2 & 2.70906 & 0 & 1 & 0 & 0 & 60.2 & 49.5 \\
\hline $99 \%$ & 45 & 65 & 531.82 & 160 & 21.6767 & 19.091 & 5 & 1 & 1 & 97 & 68 \\
\hline Observations & 18 & 17 & 15 & 23 & 19 & 23 & 23 & 23 & 23 & 8 & 8 \\
\hline Cayman Islands & 0.09 & 2.245 & -27.56 & 100 & 2.88249 & 2.587 & 4 & 1 & 1 & 61.8 & 43.215 \\
\hline $1 \%$ & -19.29 & -62.775 & -99.06 & 10 & 0.58831 & 0 & 1 & 0 & 0 & 4.83 & 4.19 \\
\hline $99 \%$ & 353.85 & 222.47 & 332.5 & 1144.75 & 16.3511 & 15 & 9 & 1 & 1 & 100 & 78.6 \\
\hline Observations & 97 & 100 & 92 & 119 & 116 & 119 & 119 & 119 & 119 & 49 & 48 \\
\hline
\end{tabular}




\section{Table 7 continued.}

\begin{tabular}{|c|c|c|c|c|c|c|c|c|}
\hline & $\begin{array}{c}\text { Proceeds } \\
\text { million USD }\end{array}$ & $\begin{array}{l}\text { Expense } \\
\text { percent }\end{array}$ & $\begin{array}{c}\text { Over- } \\
\text { allotment } \\
\text { Percent }\end{array}$ & $\begin{array}{c}\text { Number of lead } \\
\text { managers }\end{array}$ & $\begin{array}{l}\text { Lock-up } \\
\text { dummy }\end{array}$ & $\begin{array}{l}\text { Venture capital } \\
\text { dummy }\end{array}$ & $\begin{array}{c}\text { Percent insiders } \\
\text { before offer }\end{array}$ & $\begin{array}{c}\text { Percent insiders } \\
\text { after offer }\end{array}$ \\
\hline IPO return 1 day & 0.04102 & -0.00139 & 0.00683 & -0.02199 & -0.17614 & -0.0713 & -0.11305 & -0.02792 \\
\hline $\mathrm{p}$-value & 0.6089 & 0.9871 & 0.9321 & 0.7839 & 0.0268 & 0.3733 & 0.3898 & 0.8352 \\
\hline Observations & 158 & 139 & 158 & 158 & 158 & 158 & 60 & 58 \\
\hline IPO return 90 days & 0.02941 & -0.01068 & 0.01584 & -0.02155 & -0.17334 & -0.06293 & -0.1712 & -0.08271 \\
\hline p-value & 0.7094 & 0.8989 & 0.841 & 0.7848 & 0.0269 & 0.4248 & 0.1834 & 0.5298 \\
\hline Observations & 163 & 144 & 163 & 163 & 163 & 163 & 62 & 60 \\
\hline IPO return 1 year & 0.02875 & -0.01666 & 0.03774 & -0.03291 & -0.19022 & -0.07346 & -0.20214 & -0.16381 \\
\hline p-value & 0.726 & 0.8497 & 0.6454 & 0.6883 & 0.0193 & 0.3701 & 0.1182 & 0.2151 \\
\hline Observations & 151 & 132 & 151 & 151 & 151 & 151 & 61 & 59 \\
\hline
\end{tabular}


Supplement to Table 1 Panel B. Other countries of incorporation or address

Other Country of Incorporation

\begin{tabular}{|c|c|c|c|c|c|c|c|c|c|c|c|c|c|c|c|}
\hline \multicolumn{16}{|l|}{ Address } \\
\hline Country & AG & AI & BB & $\mathrm{BZ}$ & $\mathrm{CK}$ & $\mathrm{CN}$ & GI & HK & IE & LI & LU & $\mathrm{MC}$ & MT & SE & SG \\
\hline HK & 0 & 0 & 0 & 0 & 0 & 1 & 0 & 0 & 0 & 0 & 0 & 0 & 0 & 0 & 0 \\
\hline $\mathrm{CN}$ & 2 & 0 & 0 & 0 & 0 & 0 & 0 & 1 & 0 & 0 & 0 & 0 & 0 & 0 & 0 \\
\hline GB & 0 & 0 & 0 & 1 & 0 & 0 & 3 & 0 & 1 & 0 & 1 & 0 & 1 & 0 & 0 \\
\hline US & 0 & 2 & 0 & 0 & 1 & 0 & 0 & 0 & 1 & 1 & 0 & 0 & 0 & 0 & 0 \\
\hline $\mathrm{SG}$ & 0 & 0 & 0 & 0 & 0 & 0 & 0 & 0 & 0 & 0 & 0 & 0 & 0 & 0 & 0 \\
\hline GR & 0 & 0 & 0 & 0 & 0 & 0 & 0 & 0 & 0 & 0 & 0 & 0 & 0 & 0 & 0 \\
\hline $\mathrm{CA}$ & 0 & 0 & 1 & 0 & 0 & 0 & 0 & 0 & 0 & 0 & 0 & 0 & 0 & 0 & 0 \\
\hline $\mathrm{NO}$ & 0 & 0 & 0 & 0 & 0 & 0 & 0 & 0 & 0 & 0 & 2 & 0 & 0 & 0 & 0 \\
\hline $\mathrm{AG}$ & 0 & 0 & 0 & 0 & 0 & 0 & 0 & 0 & 0 & 0 & 0 & 0 & 0 & 0 & 0 \\
\hline AT & 0 & 0 & 0 & 0 & 0 & 0 & 0 & 0 & 0 & 0 & 0 & 0 & 0 & 0 & 0 \\
\hline $\mathrm{AU}$ & 0 & 0 & 0 & 0 & 0 & 0 & 0 & 0 & 0 & 0 & 0 & 0 & 0 & 0 & 0 \\
\hline $\mathrm{BE}$ & 0 & 0 & 0 & 0 & 0 & 0 & 0 & 0 & 0 & 0 & 1 & 0 & 0 & 0 & 0 \\
\hline $\mathrm{BM}$ & 0 & 0 & 0 & 0 & 0 & 0 & 0 & 0 & 1 & 0 & 0 & 0 & 0 & 0 & 0 \\
\hline $\mathrm{BZ}$ & 0 & 0 & 0 & 0 & 0 & 0 & 0 & 0 & 0 & 0 & 0 & 0 & 0 & 0 & 0 \\
\hline $\mathrm{CH}$ & 0 & 0 & 0 & 0 & 0 & 0 & 0 & 0 & 0 & 1 & 1 & 0 & 0 & 0 & 0 \\
\hline $\mathrm{DE}$ & 0 & 0 & 0 & 0 & 0 & 0 & 0 & 0 & 0 & 0 & 0 & 0 & 0 & 0 & 0 \\
\hline DK & 0 & 0 & 0 & 0 & 0 & 0 & 0 & 0 & 0 & 0 & 0 & 0 & 0 & 0 & 0 \\
\hline FR & 0 & 0 & 0 & 0 & 0 & 0 & 0 & 0 & 0 & 0 & 0 & 3 & 0 & 0 & 0 \\
\hline IE & 0 & 0 & 0 & 0 & 0 & 0 & 0 & 0 & 0 & 0 & 0 & 0 & 0 & 0 & 0 \\
\hline IL & 0 & 0 & 0 & 0 & 0 & 0 & 0 & 0 & 0 & 0 & 0 & 0 & 0 & 0 & 0 \\
\hline JP & 0 & 0 & 0 & 0 & 0 & 0 & 0 & 0 & 0 & 0 & 0 & 0 & 0 & 0 & 0 \\
\hline KR & 0 & 0 & 0 & 0 & 0 & 0 & 0 & 0 & 0 & 0 & 0 & 0 & 0 & 0 & 0 \\
\hline LU & 0 & 0 & 0 & 0 & 0 & 0 & 0 & 0 & 0 & 0 & 0 & 0 & 0 & 1 & 0 \\
\hline MX & 0 & 0 & 0 & 0 & 0 & 0 & 0 & 0 & 0 & 0 & 0 & 0 & 0 & 0 & 0 \\
\hline MY & 0 & 0 & 0 & 0 & 0 & 0 & 0 & 0 & 0 & 0 & 0 & 0 & 0 & 0 & 0 \\
\hline NL & 0 & 0 & 0 & 0 & 0 & 0 & 0 & 0 & 0 & 0 & 0 & 0 & 0 & 0 & 0 \\
\hline $\mathrm{PE}$ & 0 & 0 & 0 & 0 & 0 & 0 & 0 & 0 & 0 & 0 & 0 & 0 & 0 & 0 & 0 \\
\hline RU & 0 & 0 & 0 & 0 & 0 & 0 & 0 & 0 & 0 & 0 & 0 & 0 & 0 & 0 & 0 \\
\hline TW & 0 & 0 & 0 & 0 & 0 & 0 & 0 & 0 & 0 & 0 & 0 & 0 & 0 & 0 & 2 \\
\hline $\mathrm{TZ}$ & 0 & 0 & 0 & 0 & 0 & 0 & 0 & 0 & 0 & 0 & 0 & 0 & 0 & 0 & 0 \\
\hline VE & 0 & 0 & 0 & 0 & 0 & 0 & 0 & 0 & 0 & 0 & 0 & 0 & 0 & 0 & 0 \\
\hline VG & 0 & 0 & 0 & 0 & 0 & 0 & 0 & 0 & 0 & 0 & 0 & 0 & 0 & 0 & 0 \\
\hline $\mathrm{VN}$ & 0 & 0 & 0 & 0 & 0 & 0 & 0 & 0 & 0 & 0 & 0 & 0 & 0 & 0 & 0 \\
\hline ZA & 0 & 0 & 0 & 0 & 0 & 0 & 0 & 0 & 0 & 0 & 0 & 0 & 0 & 0 & 0 \\
\hline
\end{tabular}


Supplement to Table 1 Panel B continued.

\begin{tabular}{|c|c|c|c|c|c|c|c|c|c|c|c|}
\hline Other & & & & & & of Inc & & & & & \\
\hline \multicolumn{12}{|l|}{ Address } \\
\hline Country & BM & KY & VG & $\mathrm{MH}$ & JE & IM & GG & BS & PA & AN & $\mathrm{CY}$ \\
\hline AG & 0 & 0 & 1 & 0 & 0 & 0 & 0 & 0 & 0 & 0 & 0 \\
\hline AT & 0 & 0 & 0 & 0 & 1 & 0 & 0 & 0 & 0 & 0 & 0 \\
\hline$A U$ & 7 & 0 & 1 & 0 & 1 & 0 & 0 & 0 & 0 & 0 & 0 \\
\hline $\mathrm{BE}$ & 0 & 0 & 0 & 0 & 0 & 0 & 0 & 0 & 0 & 0 & 1 \\
\hline BM & 0 & 1 & 0 & 6 & 0 & 0 & 0 & 0 & 0 & 0 & 0 \\
\hline$B Z$ & 3 & 0 & 0 & 0 & 0 & 1 & 0 & 0 & 0 & 0 & 0 \\
\hline $\mathrm{CH}$ & 1 & 1 & 0 & 0 & 0 & 0 & 1 & 0 & 0 & 0 & 0 \\
\hline $\mathrm{DE}$ & 0 & 0 & 0 & 0 & 0 & 0 & 1 & 0 & 0 & 0 & 0 \\
\hline DK & 0 & 0 & 0 & 0 & 0 & 0 & 0 & 1 & 0 & 0 & 0 \\
\hline FR & 0 & 0 & 0 & 0 & 0 & 0 & 0 & 1 & 0 & 0 & 0 \\
\hline IE & 2 & 0 & 0 & 0 & 1 & 0 & 0 & 0 & 0 & 0 & 0 \\
\hline IL & 0 & 0 & 0 & 0 & 0 & 0 & 0 & 0 & 1 & 0 & 0 \\
\hline$J P$ & 0 & 1 & 0 & 0 & 0 & 0 & 0 & 0 & 0 & 0 & 0 \\
\hline $\mathrm{KR}$ & 0 & 2 & 0 & 0 & 0 & 0 & 0 & 0 & 0 & 0 & 0 \\
\hline LU & 1 & 1 & 0 & 0 & 0 & 1 & 0 & 0 & 0 & 0 & 0 \\
\hline $\mathrm{MX}$ & 0 & 0 & 0 & 0 & 0 & 0 & 0 & 0 & 1 & 0 & 0 \\
\hline MY & 2 & 0 & 0 & 0 & 2 & 0 & 0 & 0 & 0 & 0 & 0 \\
\hline NL & 2 & 0 & 0 & 0 & 0 & 0 & 0 & 1 & 0 & 4 & 0 \\
\hline PE & 1 & 0 & 0 & 0 & 0 & 0 & 0 & 1 & 1 & 0 & 0 \\
\hline $\mathrm{RU}$ & 0 & 0 & 0 & 0 & 0 & 0 & 0 & 0 & 0 & 0 & 1 \\
\hline TW & 3 & 3 & 0 & 0 & 0 & 0 & 0 & 0 & 0 & 0 & 0 \\
\hline TZ & 1 & 0 & 0 & 0 & 0 & 0 & 0 & 0 & 0 & 0 & 0 \\
\hline VE & 0 & 1 & 0 & 0 & 0 & 0 & 0 & 0 & 0 & 0 & 0 \\
\hline VG & 0 & 0 & 0 & 0 & 0 & 1 & 0 & 0 & 0 & 0 & 0 \\
\hline VN & 0 & 2 & 0 & 0 & 0 & 0 & 0 & 0 & 0 & 0 & 0 \\
\hline ZA & 2 & 0 & 4 & 0 & 0 & 0 & 1 & 0 & 0 & 0 & 0 \\
\hline
\end{tabular}

